Article

\title{
Steroid Alkaloids from Holarrhena africana with Strong Activity against Trypanosoma brucei rhodesiense
}

\author{
Charles Okeke Nnadi ${ }^{1,2}$, Ngozi Justina Nwodo ${ }^{2}$, Marcel Kaiser ${ }^{3,4}$, Reto Brun ${ }^{3,4}$ and \\ Thomas J. Schmidt ${ }^{1, *}$ \\ 1 Institute of Pharmaceutical Biology and Phytochemistry (IPBP), University of Münster, \\ PharmaCampus Corrensstraße 48, D-48149 Münster, Germany; charles.nnadi@unn.edu.ng \\ 2 Department of Pharmaceutical and Medicinal Chemistry, Faculty of Pharmaceutical Sciences, \\ University of Nigeria Nsukka, Enugu State 410001, Nigeria; ngozi.nwodo@unn.edu.ng \\ 3 Swiss Tropical and Public Health Institute (Swiss TPH), Socinstr. 57, CH-4051 Basel, Switzerland; \\ marcel.kaiser@unibas.ch (M.K.); reto.brun@unibas.ch (R.B.) \\ 4 University of Basel, Petersplatz 1, CH-4003 Basel, Switzerland \\ * Correspondence: thomschm@uni-muenster.de; Tel.: +49-251-83-33-378
}

Received: 28 June 2017; Accepted: 5 July 2017; Published: 6 July 2017

\begin{abstract}
In our continued search for natural compounds with activity against Trypanosoma brucei, causative agent of human African trypanosomiasis (HAT, "sleeping sickness"), we have investigated extracts from the leaves and bark of the West African Holarrhena africana (syn. Holarrhena floribunda; Apocynaceae). The extracts and their alkaloid-enriched fractions displayed promising in vitro activity against bloodstream forms of T. brucei rhodesiense (Tbr; East African HAT). Bioactivity-guided chromatographic fractionation of the alkaloid-rich fractions resulted in the isolation of 17 steroid alkaloids, one nitrogen-free steroid and one alkaloid-like non-steroid. Impressive activities $\left(I C_{50}\right.$ in $\mu \mathrm{M})$ against $\mathrm{Tbr}$ were recorded for $3 \beta$-holaphyllamine $(0.40 \pm 0.28), 3 \alpha$-holaphyllamine $(0.37 \pm 0.16)$, $3 \beta$-dihydroholaphyllamine $(0.67 \pm 0.03), N$-methylholaphyllamine $(0.08 \pm 0.01)$, conessimine $(0.17 \pm 0.08)$, conessine $(0.42 \pm 0.09)$, isoconessimine $(0.17 \pm 0.11)$ and holarrhesine $(0.12 \pm 0.08)$ with selectivity indices ranging from 13 to 302. Based on comparison of the structures of this congeneric series of steroid alkaloids and their activities, structure-activity relationships (SARs) could be established. It was found that a basic amino group at position C-3 of the pregnane or pregn-5-ene steroid nucleus is required for a significant anti-trypanosomal activity. The mono-methylated amino group at C-3 represents an optimum for activity. $\Delta^{5,6}$ unsaturation slightly increased the activity while hydrolysis of $C-12 \beta$ ester derivatives led to a loss of activity. An additional amino group at $\mathrm{C}-20$ engaged in a pyrrolidine ring closed towards C-18 significantly increased the selectivity index of the compounds. Our findings provide useful empirical data for further development of steroid alkaloids as a novel class of anti-trypanosomal compounds which represent a promising starting point towards new drugs to combat human African trypanosomiasis.
\end{abstract}

Keywords: Holarrhena africana; Holarrhena floribunda; steroid alkaloid; Trypanosoma brucei rhodesiense; structure-activity relationship; anti-trypanosomal

\section{Introduction}

Human African trypanosomiasis (HAT) is a vector-borne parasitic disease caused by the kinetoplastid parasites, Trypanosoma brucei rhodesiense (Tbr) and Trypanosoma brucei gambiense (Tbg). The disease ranks 11th, 14th and 4th in the list of neglected tropical diseases (NTDs) for which disability-adjusted life years (DALYs), years of life lost (YLLs) due to mortality and years lived 
with disability (YLDs) were respectively estimated [1]. Several policy initiatives for prevention and eradication have been developed and funded by World Health Organization WHO and other international organizations [2]. These interventions have been hampered by poor access to available medications, adverse effects associated with some of the medications and incidences of resistant strains of trypanosomes. Moreover, policies geared towards control and eradication of HAT are usually impeded by incomplete and fragmented data on HAT incidence, morbidity and mortality [3] and social stigmatization of the victims in some parts of Sub-Saharan Africa [4]. In view of these obstacles, the search has been on-going to explore additional or alternative remedies from natural products with potential to eradicate HAT. Incidentally, a great number of alkaloids with anti-protozoal activity have been reported and are being explored for antitrypanosomal activity [5-15].

Holarrhena africana A. DC. (a synonym of H. floribunda (G. Don) T. Durand \& Schinz) is a tropical tree well distributed in Nigeria and other West African countries. It belongs to the Apocynaceae family which is known to be abundant in alkaloids of various structural classes [16]. Traditionally, the leaves are used in Nigeria to treat convulsion, fever and malaria while the stem bark serves as an antimicrobial, a febrifuge and an antidote for snake venom [17]. Antibacterial and antimalarial $[18,19]$ activities of the chemical constituents of $H$. africana have also been reported. A crude aqueous extract of the plant has previously been reported to show interesting preliminary in vitro anti-trypanosomal activity against $\mathrm{Tbr}$. A chemically uncharacterized fraction of the aqueous extract has also shown in vivo activity against T. brucei brucei [20]. Consequently, we investigated the crude extract and its alkaloid-enriched fraction for anti-trypanosomal activity. Since the alkaloid fraction showed very strong activity, we set out to systematically isolate the alkaloids from H. africana and to test them for anti-trypanosomal activity as well as for cytotoxic activity against mammalian cells in order to assess their selectivity and structure-activity relationships (SARs).

\section{Results and Discussion}

\subsection{Anti-Trypanosomal Activity of Crude Extracts and Alkaloid-Enriched Fractions of Holarrhena africana Leaves and Stem Bark}

The crude extracts of the fresh leaves and the dried stem bark of $H$. africana were tested for in vitro activity against Trypanosoma brucei rhodesiense (Tbr), Trypanosoma cruzi (Tcr), Leishmania donovani (Ldon) and Plasmodium falciparum (Pf) and for cytotoxicity against L6 rat skeletal myoblasts. Since it turned out that activity was selectively observed against $T b r$, the alkaloidal fraction and column chromatographic fractions were not tested against the other parasites. The results (Table 1) showed that the alkaloid-enriched fraction from the leaf extract had higher activity compared to the crude extract and the polar neutral aqueous fraction (Table 1). These findings are in line with an earlier report [20] of an uncharacterized fraction of $H$. africana leaves with anti-trypanosomal activity, even though the activity reported then was not attributed to the alkaloid content of the plant or to any other chemical characteristic. A similar trend was also observed in the activities of the stem bark extract and its alkaloid fraction. Consequently, both alkaloid fractions were considered potential sources of alkaloids with anti-trypanosomal activity and hence chosen for bioactivity-guided fractionation and isolation of active compounds.

\subsection{Bio-Activity Guided Fractionation and Isolation of Steroid Alkaloids}

The alkaloidal fraction of the leaves was fractionated into 16 fractions by column chromatography on silica gel 60. Similarly, the alkaloidal fraction of the stem bark was chromatographed on silica gel column to yield 20 major fractions. All the fractions were analyzed on TLC for the presence or absence of alkaloids using Dragendoff reagent. Positive Dragendoff reaction was obtained in four and two fractions of the leaves and stem bark respectively. The six fractions were subjected to in vitro assay against $\mathrm{Tbr}$ and higher activities were recorded for three fractions of the leaves and both fractions of the stem bark (Table 1). Further analysis of the fractions by UHPLC/+ESI 
QTOF MS/MS was carried out and the major alkaloids were partially dereplicated and marked for eventual isolation. Following repeated chromatographic separation and purification, six (1-6) and eleven (7-17) major steroid alkaloids were isolated from the leaves and stem bark respectively, in addition to one nitrogen-free steroid (18) and a non-steroid alkaloid-like compound (19) from the leaves (Figure 1). The compounds were identified as $3 \beta$-holaphyllamine (1), holaphyllamine acetamide (2), $3 \beta-N$-methylholaphyllamine (3), $3 \alpha$-holaphyllamine (4), $3 \beta$-dihydroholaphyllamine (5), 3 $\alpha$-dihydroholaphyllamine (6), holadienine (7), holonamine (8), cona-4,6-dienin-3-one (9), cona-3,5-dienin-7-one (10), conessimine (11), isoconessimine (12), conessine (13), holarrhesine (14), holarrhetine (15), holarrheline (16), holarrhenine (17), kurchinin (18) and $N^{3}$-isopentenyl adenine (19) by comparison of their 1D and 2D NMR data and their exact masses from UHPLC/+ESI QTOF MS/MS analysis, which were in agreement with previously reported data [21-31].

Table 1. In vitro anti-trypanosomal and cytotoxic activity of crude extracts, alkaloid fraction and CC fractions of $H$. africana leaves and stem bark.

\begin{tabular}{ccccccc}
\hline \multirow{2}{*}{$\begin{array}{c}\text { Tested } \\
\text { Substance }\end{array}$} & \multicolumn{3}{c}{ Leaves } & \multicolumn{3}{c}{ Stem bark } \\
\cline { 2 - 7 } & Tbr & Cytotox. L6 & SI & Tbr & Cytotox. L6 & SI \\
\hline Crude extract & $4.70^{\mathrm{c}}$ & $87.5^{\mathrm{c}}$ & 18.6 & $0.708 \pm 0.013$ & $>100$ & $>100$ \\
Alk. fraction & $0.905 \pm 0.405$ & $43.8^{\mathrm{c}}$ & 48.4 & $0.143 \pm 0.091$ & $16.85 \pm 1.344$ & 117.8 \\
Polar fraction & $54.4^{\mathrm{c}}$ & n.t. & n.a. & $35.2 \pm 25.4$ & $>100$ & n.a. \\
Fraction 11 & $1.87 \pm 1.8$ & n.t. & n.a. & $0.960 \pm 0.325^{\mathrm{a}}$ & $>100$ & $>100$ \\
Fraction 12 & $0.191 \pm 0.001$ & n.t. & n.a. & $0.225 \pm 0.012^{\mathrm{b}}$ & $>100$ & $>100$ \\
Fraction 13 & $0.031 \pm 0.005$ & n.t. & n.a. & n.a. & n.a. & n.a. \\
Fraction 14 & $0.219 \pm 0.004$ & n.t. & n.a. & n.a. & n.a. & n.a. \\
Pos. control & $0.002 \pm 0.001$ & $0.004 \pm 0.001$ & n.a. & $0.002 \pm 0.001$ & $0.004 \pm 0.001$ & n.a. \\
\hline
\end{tabular}

Data are average of two independent determinations, $I C_{50} \pm$ deviation from mean value, n.a. = not applicable, n.t. $=$ not tested, ${ }^{\mathrm{a}}$ fraction HF8, ${ }^{\mathrm{b}}$ fraction HF9, ${ }^{\mathrm{c}}$ one replicate was used to determine $I C_{50}$, positive controls: melarsoprol (Tbr), podophyllotoxin (cytotoxic L6), selectivity indices $(\mathrm{SI})=$ cytotoxic $I C_{50}(\mathrm{~L} 6) / I C_{50} T b r$.

\subsection{In Vitro Anti-Trypanosomal Activity of Isolated Compounds}

All the isolated compounds were tested for in vitro anti-trypanosomal activity against $\mathrm{Tbr}$ and for cytotoxicity against L6 rat skeletal myoblasts. Impressive anti-trypanosomal activities $\left(\mathrm{IC}_{50}, \mathrm{Tbr}\right.$ $<1.0 \mu \mathrm{M}$ ) were recorded for compounds 1, 3-5, 11-14. Compounds 2, 6 and 15 showed moderate activities $\left(I C_{50}, 1-5 \mu \mathrm{M}\right)$ while compounds $\mathbf{7 - 1 0 , 1 6 - 1 9}$ were of low activity with $I C_{50}>7 \mu \mathrm{M}$ (Table 2 ). Interestingly, four steroid alkaloids, 11-14 showed very high activity in addition to SI > 100 .

Table 2. In vitro anti-trypanosomal activity and cytotoxicity of isolated alkaloids.

\begin{tabular}{|c|c|c|c|c|c|c|}
\hline \multirow[b]{2}{*}{ Compounds } & & \multicolumn{2}{|c|}{ Tbr (STIB900) } & \multicolumn{2}{|c|}{ Cytotoxicity L6 Cells } & \multirow[b]{2}{*}{ SI } \\
\hline & & $\begin{array}{c}I C_{50} \\
(\mu \mathrm{g} / \mathrm{mL})\end{array}$ & $I C_{50}(\mu \mathrm{M})$ & $\begin{array}{c}I C_{50} \\
(\mu \mathrm{g} / \mathrm{mL})\end{array}$ & $I C_{50}(\mu \mathrm{M})$ & \\
\hline $3 \beta$-Holaphyllamine & (1) & $0.127 \pm 0.088$ & $0.402 \pm 0.281$ & $1.61 \pm 0.21$ & $5.10 \pm 0.65$ & 12.6 \\
\hline Holaphyllamine acetamid & $(2)$ & $1.73 \pm 0.47$ & $4.83 \pm 1.33$ & $5.49 \pm 0.33$ & $15.4 \pm 0.9$ & 3.2 \\
\hline$N$-methylholaphyllamine & (3) & $0.025 \pm 0.001$ & $0.075 \pm 0.004$ & $0.829 \pm 0.124$ & $2.48 \pm 0.44$ & 33.2 \\
\hline $3 \alpha$-Holaphyllamine & $(4)$ & $0.117 \pm 0.050$ & $0.370 \pm 0.159$ & $5.00 \pm 0.37$ & $15.87 \pm 1.17$ & 42.9 \\
\hline $3 \beta$-Dihydroholaphyllamine & (5) & $0.213 \pm 0.008$ & $0.672 \pm 0.027$ & $5.51 \pm 0.43$ & $17.37 \pm 1.36$ & 25.8 \\
\hline $3 \alpha$-Dihydroholaphyllamine & (6) & $0.382 \pm 0.238$ & $1.21 \pm 0.75$ & $5.38 \pm 0.39$ & $17.0 \pm 1.2$ & 14.1 \\
\hline Holadienine & (7) & $4.81 \pm 0.68$ & $14.9 \pm 2.1$ & n.t. & n.t. & n.t. \\
\hline Holonamine & $(8)$ & $2.82 \pm 0.76$ & $8.67 \pm 2.33$ & $21.1 \pm 7.5$ & $64.9 \pm 23.1$ & 7.5 \\
\hline Cona-4,6-dienin-3-one & (9) & $5.69 \pm 0.07$ & $17.5 \pm 0.2$ & $41.9 \pm 19.9$ & $129 \pm 61$ & 7.4 \\
\hline Cona-3,5-dienin-7-one & (10) & $2.40 \pm 0.30$ & $7.37 \pm 0.94$ & $13.6 \pm 6.2$ & $41.7 \pm 18.9$ & 5.7 \\
\hline Conessimine & (11) & $0.057 \pm 0.028$ & $0.167 \pm 0.083$ & $17.3 \pm 4.0$ & $50.4 \pm 11.8$ & 302 \\
\hline Isoconessimine & (12) & $0.056 \pm 0.038$ & $0.166 \pm 0.112$ & $9.38^{\mathrm{a}}$ & 27.4 & 168 \\
\hline
\end{tabular}


Table 2. Cont

\begin{tabular}{|c|c|c|c|c|c|c|}
\hline \multirow[b]{2}{*}{ Compounds } & & \multicolumn{2}{|c|}{ Tbr (STIB900) } & \multicolumn{2}{|c|}{ Cytotoxicity L6 Cells } & \multirow[b]{2}{*}{ SI } \\
\hline & & $\begin{array}{c}I C_{50} \\
(\mu \mathrm{g} / \mathrm{mL})\end{array}$ & $I C_{50}(\mu \mathrm{M})$ & $\begin{array}{c}I C_{50} \\
(\mu \mathrm{g} / \mathrm{mL})\end{array}$ & $I C_{50}(\mu \mathrm{M})$ & \\
\hline Conessine & (13) & $0.149 \pm 0.031$ & $0.419 \pm 0.087$ & $21.8^{\mathrm{a}}$ & 61.2 & 146 \\
\hline Holarrhesine & (14) & $0.054 \pm 0.038$ & $0.119 \pm 0.084$ & $6.51^{\mathrm{a}}$ & 14.3 & 121 \\
\hline Holarrhetine & (15) & $0.777 \pm 0.182$ & $1.66 \pm 0.39$ & $45.8^{\mathrm{a}}$ & 97.7 & 58.9 \\
\hline Holarrheline & (16) & $2.94 \pm 0.37$ & $8.21 \pm 1.03$ & $64.8 \pm 14.2$ & $181 \pm 40$ & 22.0 \\
\hline Holarrhenine & (17) & $7.78 \pm 2.23$ & $20.9 \pm 6.0$ & $46.4 \pm 12.8$ & $125 \pm 34$ & 6.0 \\
\hline kurchinin & (18) & $3.64 \pm 0.21$ & $12.1 \pm 0.7$ & n.t. & n.t. & n.a. \\
\hline Isopentenyl adenine & (19) & $5.03 \pm 0.54$ & $24.78 \pm 0.84$ & $61.30 \pm 4.24$ & $302 \pm 6.80$ & 12.2 \\
\hline
\end{tabular}

Data represent the average of two independent determinations, $I C_{50} \pm$ absolute deviation from mean value, n.a. $=$ not applicable, n.t. = not tested, ${ }^{\text {a }}$ one replicate was used to determine $I C_{50}$, Positive controls are shown in Table 1.

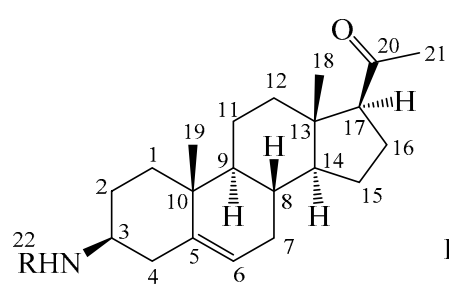

1: $\mathrm{R}=\mathrm{H}, \mathbf{2}: \mathrm{R}=\mathrm{COCH}_{3}, \mathbf{3}: \mathrm{R}=\mathrm{CH}_{3}$

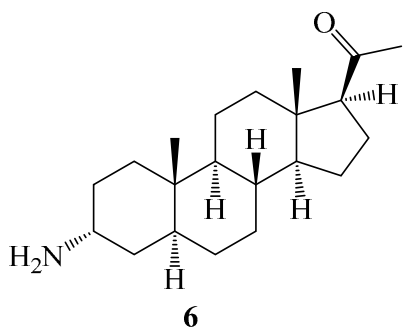<smiles>CC1[C@H]2CC[C@H]3[C@H]4C=CC5=CC(=O)CC[C@]5(C)[C@H]4CC[C@]23CN1C</smiles>

9

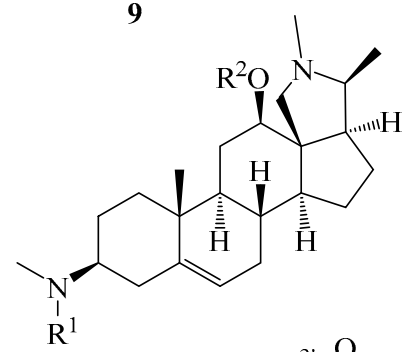
14: $\mathrm{R}^{1}=\mathrm{H}, \mathrm{R}^{2}=\left.4^{\prime}\right|_{2^{\prime}} ^{\prime} \mathrm{H}^{\prime}$
15: $\mathrm{R}^{1}=\mathrm{CH}_{3}, \mathrm{R}^{2}=$
16: $R^{1}=R^{2}=H$
17: $\mathrm{R}^{1}=\mathrm{CH}_{3}, \mathrm{R}^{2}=\mathrm{H}$<smiles>CC(=O)[C@H]1CC[C@H]2[C@@H]3CC=C4C[C@@H](N)CC[C@]4(C)[C@H]3CC[C@@]12C</smiles>

4<smiles>C[C@@H]1[C@@H](C)N(C)C[C@@]23CC[C@H]4[C@H](CCC5=CC(=O)C=C[C@@]54C)[C@@H]2CC[C@H]13</smiles>

7<smiles>CC1[C@@H](C)[C@H]2CC[C@@H]3[C@H](CC[C@]12C)[C@H]1[C@H]3C(=O)C=C2C=CCC[C@@]21C</smiles>

10<smiles>C[C@@]12C=CC(=O)C=C1CC[C@H]1[C@H]2[C@H](O)C[C@]2(C)C(=O)CC[C@H]12</smiles>

18<smiles>CC(=O)[C@H]1CC[C@H]2[C@@H]3CC[C@H]4C[C@@H](N)CC[C@]4(C)[C@H]3CC[C@]12C</smiles>

5

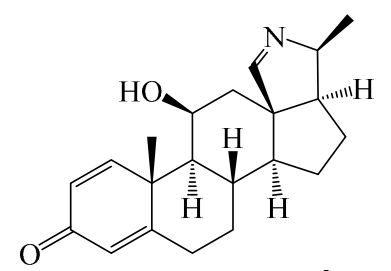

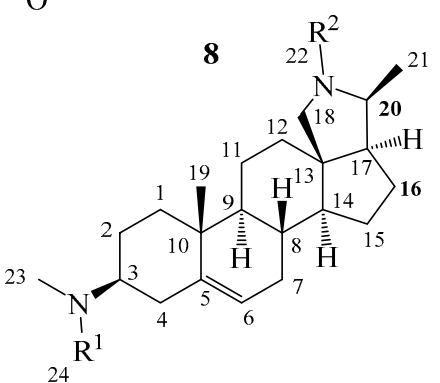

11: $\mathrm{R}^{1}=\mathrm{CH}_{3}, \mathrm{R}^{2}=\mathrm{H}$

12: $\mathrm{R}^{1}=\mathrm{H}, \mathrm{R}^{2}=\mathrm{CH}_{3}$

13: $\mathrm{R}^{1}=\mathrm{R}^{2}=\mathrm{CH}_{3}$<smiles>CC(C)=CCn1cnc(N)c2ncnc1-2</smiles>

Figure 1. Compounds isolated from the leaves $(\mathbf{1 - 6 , 1 9 )}$ and stem bark $(\mathbf{7 - 1 8})$ of Holarrhena africana. 


\subsection{Structure-Activity and-Selectivity Relationships}

A comparison of all isolated and tested steroidal compounds revealed some structure-activity relationships, as represented in Figure 2.

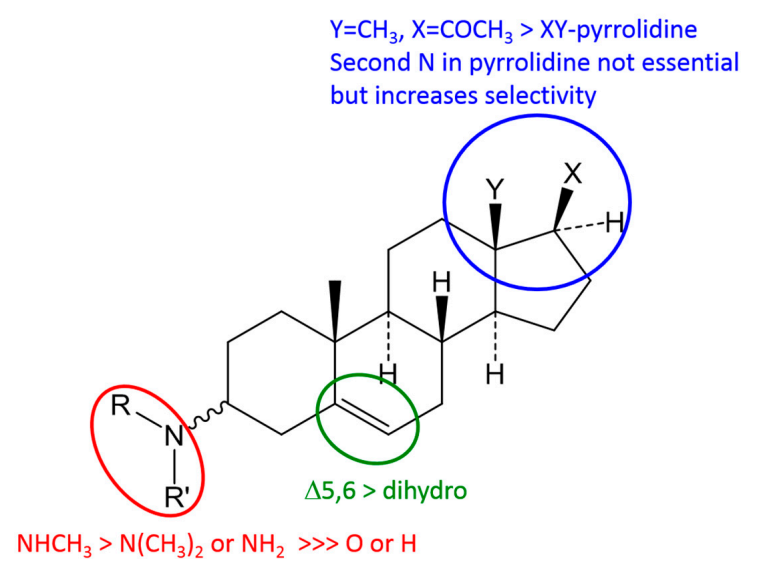

Figure 2. Proposed basic structure-activity relationships for anti-trypanosomal activity. >sign indicates higher activity.

The major structural requirement for a strong anti-trypanosomal activity against $\operatorname{Tbr}\left(I_{50}<1 \mu \mathrm{M}\right)$ is a basic amino group at C-3 of the steroid nucleus. Compounds without an amino group in this position such as 7-10 and $\mathbf{1 8}$ and also the acetamide $\mathbf{2}$ are considerably less active $\left(I C_{50}\right.$ between 4.8 and $14.9 \mu \mathrm{M})$. With respect to substitution of the 3-amino group, monomethylation appears to represent an optimum as observed when comparing monomethylated with unsubstituted (3 more active than 1), and monomethylated with dimethylated congeners $(\mathbf{1 2}, 14,16$ more active than 13, 15 and 17, respectively). Comparing the $\Delta^{5,6}$-pregnene derivatives holaphyllamine (1) and its $3 \alpha$-amino analogue (4) with their two pregnane congeners 5 and $\mathbf{6}$, respectively, shows that the double bond causes a slight increase of activity. Even though $\mathbf{5}$ with a $3 \beta$-amino group is slightly more potent than the $\alpha$-configured 6 , the effect of stereochemistry at the 3-position appears to be small as indicated by comparison of $\mathbf{1}$ with $\mathbf{4}$ which are almost equipotent.

It is very interesting to note that an amino group as part of a pyrrolidine or pyrroline ring connecting C-20 with C-18, as present in compounds $\mathbf{7 - 1 7}$, on its own does not confer high activity (see low activity of 7-10) but rather appears to lead to a slight decrease in antitrypanosomal potency if it occurs together with the 3-amino group (compare 12 with 3). However, when combined with the C-3 amino function as in 11-17, this structural element leads to a marked decrease of cytotoxicity and increase in selectivity (e.g., SI = 33 in case of 3 and 168 for 12). This effect is strongest in compound 11 which is not methylated at the pyrrolidine amino group and shows a very favourable SI $>300$.

Finally, the introduction of a lipophilic acyloxy substituent at C-12 as in $\mathbf{1 4}$ and $\mathbf{1 5}$ does not lead to dramatic effects on activity in comparison with the compounds unsubstituted at this position (12 and 13, respectively). However, deacylation of such esters leading to a free $\mathrm{OH}$ group at C-12 renders compounds 16 and 17 significantly less active.

\section{Materials and Methods}

\subsection{General Experimental Procedures}

Analytical and preparative TLC were performed on pre-coated, silica gel 60 F254 (Merck Chemicals GmbH, Darmstadt, Germany) with various solvent systems consisting of n-hexane, ethyl acetate and methanol saturated with aqueous ammonia as the mobile phase. The plates were visualized under UV-light at 254/360 nm and then sprayed with Dragendoff's reagent. 


\subsection{Plant Material}

The leaves and stem bark of Holarrhena africana were collected in March 2015 and April 2016 respectively from a forest reserve in Nsukka $\left(6^{\circ} 51^{\prime} 28^{\prime \prime} \mathrm{N}, 7^{\circ} 23^{\prime} 44^{\prime \prime} \mathrm{E}\right)$, Nigeria. The identities were confirmed by comparison with a voucher specimen (No. 1342003) stored in the herbarium of the Department of Pharmacognosy and Environmental Medicines, University of Nigeria Nsukka. A voucher specimen of this present collection was deposited at the herbarium of the Institute of Pharmaceutical Biology and Phytochemistry, University of Münster (voucher No. TS-HA-01). The stem bark was air dried at room temperature and ground to $1 \mathrm{~mm}$ mesh size. The fresh leaves were washed with distilled water and allowed to drain completely.

\subsection{Extraction and Preparation of Alkaloid-Enriched Fractions}

Fresh leaves: A $2 \mathrm{~kg}$ fresh weight of the leaves was extracted as previously described [20]. The extract was filtered and lyophilized for $18 \mathrm{~h}$ to dry weight of $28.6 \mathrm{~g}$. The crude extract was re-dissolved in $10 \% v / v \mathrm{MeOH} /$ distilled water (in portions of $1.0 \mathrm{~g}$ to $50 \mathrm{~mL}$ ) and basified with $1 \% v / v \mathrm{NH}_{4} \mathrm{OH}$ to $\mathrm{pH}$ 12. The mixture was partitioned five times successively with $\mathrm{CH}_{2} \mathrm{Cl}_{2}$ (in portions of 1:1 ratio) in a separatory funnel. The combined lower phase was evaporated completely to yield $8.4 \mathrm{~g}(28.6 \%$ of crude extract) of alkaloid-enriched (AFL) fraction, $5.2 \mathrm{~g}$ of precipitate and $14.7 \mathrm{~g}$ polar aqueous fraction.

Stem bark: The dry powdered stem bark ( $500 \mathrm{~g}$, in portions of $5 \times 100 \mathrm{~g}$ ) was extracted exhaustively for $12 \mathrm{~h}$ in a Soxhlet apparatus with a total of $4.0 \mathrm{~L}$ dichloromethane. The solvent was evaporated in vacuo at $40{ }^{\circ} \mathrm{C}$. The extract yield was $58.6 \mathrm{~g}$. The resulting crude extract $(50 \mathrm{~g})$ was re-dissolved in several portions of $10 \% v / v \mathrm{MeOH} /$ water in a ratio of $50 \mathrm{~mL} / 1 \mathrm{~g}$ extract, basified as described above and subsequently partitioned successively with $\mathrm{CH}_{2} \mathrm{Cl}_{2}$ in a separatory funnel to yield $14.5 \mathrm{~g}$ of alkaloid-enriched fraction (AFS), $8.1 \mathrm{~g}$ of precipitate, and $26.6 \mathrm{~g}$ polar aqueous fraction.

The crude extracts and alkaloid-enriched fractions were tested for anti-trypanosomal activity and cytotoxicity (see Table 1).

\subsection{Isolation of Steroid Alkaloids}

\subsubsection{Isolation of Alkaloids from the Leaf Extract}

The major part ( $8 \mathrm{~g}$ ) of the AFL was subjected to column chromatographic (CC) separation on $560 \mathrm{~g}$ silica gel (E. Merck, type-60, 70-230 mesh) and eluted with gradients of (50\% n-hexane to $100 \%$ EtOAc) $n$-hexane-EtOAc mixture $v / v$, each gradient saturated with $\mathrm{NH}_{4} \mathrm{OH}(25 \% v / v)$. The mobile phase solvent was constituted as follows: $2 \mathrm{~L}$ each of 1:1, 3:7 and 1:9, followed by $6 \mathrm{~L}$ EtOAc and finally EtOAc:MeOH (9.9:0.1). The flow rate was maintained at $1 \mathrm{~mL} / \mathrm{min}$. The eluates were analyzed at pre-determined intervals and based on their TLC profiles and positive reaction to Dragendoff's spraying reagent, representative tubes (127-305) were collected and pooled to yield four alkaloid-containing sub-fractions, HA11 (1250 mg), HA12 (750 mg), HA13 (1680 mg) and HA14 $(480 \mathrm{mg}$ ). These sub-fractions were tested for anti-trypanosomal activity (Table 1). Compound 19 $(25.8 \mathrm{mg})$ was obtained as pure crystal by repeatedly washing sub-fraction HA11 with n-hexane. HA12 $(700 \mathrm{mg})$ was re-chromatographed on silica gel 60 and eluted isocratically with $\mathrm{NH}_{4} \mathrm{OH}$ saturated-EtOAc and at flow rate of $0.5 \mathrm{~mL} / \mathrm{min}$. Compound $2(10.0 \mathrm{mg})$ crystallized as white flaky substance while compound $\mathbf{1}(6.8 \mathrm{mg})$ was isolated after further purification on sephadex LH20 gel eluted with $\mathrm{MeOH}: \mathrm{H}_{2} \mathrm{O}$, 9:1. HA13 (1600 mg) was further separated by column chromatography on $80 \mathrm{~g}$ basic alumina with EtOAc:MeOH (9:1) as mobile phase to yield three sub-fractions (HA13a, HA13b, and HA13c). Compound $3(52 \mathrm{mg})$ was isolated as a sticky white creamy solid from sub-fraction HA13b (220 mg) by repeatedly washing with $n$-hexane:EtOAc (9:1). HA13a (120 mg) was further chromatographed on a pre-coated preparative TLC plates (GF-254, $20 \times 20 \mathrm{~cm}$, E. Merck, $0.20 \mathrm{~mm}$ thickness, Darmstadt, Germany) developed in pre-equilibrated TLC tank containing EtOAc:MeOH (9.5:0.5) and saturated with $\mathrm{NH}_{4} \mathrm{OH}$. The plates were scrapped according to bands identified after spraying a $2 \times 20 \mathrm{~cm}$ cut-off segment of the plate with Dragendoff reagent, re-extracted and washed 
with EtOAc to furnish compounds 4 ( $2.5 \mathrm{mg}$; hRf 36) and 6 ( $3.8 \mathrm{mg}$; hRf 23). HA14 and HA13c (80 $\mathrm{mg}$ ) were combined and further separated by CC on Sephadex LH-20 using $\mathrm{MeOH}: \mathrm{H}_{2} \mathrm{O}$ (8:2) as eluent. The alkaloid-positive eluates were pooled and further purified on preparative TLC (silica gel 60, in $\mathrm{NH}_{4} \mathrm{OH}$-saturated EtOAc) to furnish compound 5 (4.1 mg, hRf 22) as a creamy solid.

\subsubsection{Isolation of Alkaloids from the Stem Bark Extract}

Similarly, a major portion (12.0 g) of AFS was subjected to CC on $900 \mathrm{~g}$ silica gel 60 . The column was eluted with mobile phase solvents of increasing polarity, as described above. The eluates were analyzed by TLC and, based on a positive reaction to Dragendoff reagent, it was observed that most of the alkaloidal bands were overlapping. Therefore, alkaloid positive eluates were pooled in two fractions, HF8 (eluates 86-232; $3.85 \mathrm{~g}$ ) and HF9 (eluates 233-480; $5.33 \mathrm{~g}$ ). These fractions were also tested for anti-trypanosomal activity (Table 1). HF8 (3.8 g) was re-chromatographed over $270 \mathrm{~g}$ silica gel 60 . The column was eluted with $5.0 \mathrm{~L}$ of EtOAc $(100 \%)$ saturated with $\mathrm{NH}_{4} \mathrm{OH}$ at a flow rate of $0.8 \mathrm{~mL} / \mathrm{min}$. 205 eluates were collected and representative fractions pooled into five sub-fractions (HF8a-HF8e) based on the positive reaction to the Dragendoff reagent. HF8a (80 mg) was purified on basic alumina with EtOAc:MeOH (9.5:0.5) as eluent to yield compound 10 (9.6 mg). HF8b $(108 \mathrm{mg})$ and HF8c (228 mg) were combined and re-chromatographed on silica gel 60 and eluted with n-hexane:EtOAc (2:8) saturated with $\mathrm{NH}_{4} \mathrm{OH}$ to yield compounds 9 and 7 as a mixture. The mixture was separated on pre-coated preparative TLC silica plates in EtOAc $(100 \%)$ saturated with $\mathrm{NH}_{4} \mathrm{OH}$ to yield $5.6 \mathrm{mg}$ of 9 (hRf 65) and $4.2 \mathrm{mg}$ of 7 (hRf 60) respectively. HF8d (210 mg) was chromatographed on silica gel 60 and eluted subsequently with EtOAc (100\%) to yield crystals of 18 (3.8 mg) and then with EtOAc- $-\mathrm{NH}_{4} \mathrm{OH}$ to yield $8(7.9 \mathrm{mg})$ as white solid. HF8e $(675 \mathrm{mg})$ was further separated on silica gel $60(50 \mathrm{~g})$ with EtOAc $(100 \%)$ saturated with $\mathrm{NH}_{4} \mathrm{OH}$, flow rate $0.5 \mathrm{~mL} / \mathrm{min}$ to yield two sticky sub-fractions which were further purified on pre-coated preparative TLC with $\mathrm{NH}_{4} \mathrm{OH}$-saturated EtOAc as mobile phase to furnish 15 (16.7 mg, hRf 55) and 14 (15.6 mg; hRf 48). HF9 (5.0 g) was re-chromatographed on silica gel 60 (300 g) and eluted with $2.5 \mathrm{~L} \mathrm{EtOAc}(100 \%)$ followed by $3.0 \mathrm{~L}$ EtOAc: $\mathrm{MeOH}$ (9.8:0.2) both saturated with $\mathrm{NH}_{4} \mathrm{OH}$ to yield three sub-fractions, $\mathrm{HF9a}(860 \mathrm{mg}), \mathrm{HF9b}$ $(510 \mathrm{mg})$ and $\mathrm{HF9c}(1050 \mathrm{mg})$. HF9a yielded further $\mathbf{1 4}$ and $\mathbf{1 5}$ in a mixture. HF9b was purified by CC on basic alumina with EtOAc:MeOH (8:2) as mobile phase to yield 13 (3.8 mg) and 12 (4.1 mg). HF9c yielded $\mathbf{1 7}$ (8.8 mg; hRf 58), 11 (10.8 mg; hRf 50) and $\mathbf{1 6}$ (5.2 mg; hRf 39) after further separation by CC on silica with EtOAc:MeOH (9:1) satutated with $\mathrm{NH}_{4} \mathrm{OH}$ as mobile phase and subsequent purification by preparative TLC (silica 60, EtOAc: $\mathrm{MeOH}$ (8:2) saturated with $\mathrm{NH}_{4} \mathrm{OH}$ as mobile phase).

\subsubsection{Preparation of Compounds 16 and $\mathbf{1 7}$ by Alkaline Hydrolysis of the Esters 14 and 15}

To increase the yields and further confirm 16 and 17, a simple, efficient and reliable ester hydrolysis, without racemization or other undesirable side reaction protocol [32] was adopted. $10 \mathrm{mg}$ each of compound 14 and 15 was respectively hydrolyzed in $\mathrm{CH}_{2} \mathrm{Cl}_{2}$ using $0.5 \mathrm{~N} \mathrm{NaOH}$ (dissolved in $\mathrm{MeOH}$ ) at room temperature for $2 \mathrm{~h} ; \mathrm{CH}_{2} \mathrm{Cl}_{2}: \mathrm{MeOH}(9: 1)$. The reaction mixtures were stirred vigorously and monitored by TLC until completion and purified by preparative TLC as previously described. The yield in each case was $>70 \%$.

\subsection{Structural Characterization of Isolated Compounds}

NMR spectra $\left({ }^{1} \mathrm{H},{ }^{13} \mathrm{C},{ }^{1} \mathrm{H} /{ }^{1} \mathrm{H} \mathrm{COSY},{ }^{1} \mathrm{H} /{ }^{1} \mathrm{H}\right.$ NOESY, ${ }^{1} \mathrm{H} /{ }^{13} \mathrm{C} \mathrm{HSQC}$, and $\left.{ }^{1} \mathrm{H} /{ }^{13} \mathrm{C} \mathrm{HMBC}\right)$ were recorded on Agilent DD2 400 or $600 \mathrm{MHz}$ spectrometers at $25{ }^{\circ} \mathrm{C}$ in $\mathrm{CDCl}_{3}$ or $\mathrm{CD}_{3} \mathrm{OD}$. Spectra were respectively referenced to the $\mathrm{CDCl}_{3}$ solvent signals of ${ }^{1} \mathrm{H} ; 7.260 \mathrm{ppm}$ and ${ }^{13} \mathrm{C} ; 77.000 \mathrm{ppm}$ or $\mathrm{CD}_{3} \mathrm{OD}$ solvent signals of ${ }^{1} \mathrm{H} ; 3.310 \mathrm{ppm}$ and ${ }^{13} \mathrm{C} ; 49.000 \mathrm{ppm}$ and processed with MestRENOVA v. 11 (Mestrelab Research, Chemistry Software Solutions, Santiago de Compostela, Spain) software. 


\subsection{Spectral Data of Isolated Compounds}

3ß-Holaphyllamine 1: hRf (silica gel 60 tlc, EtOAc:MeOH, 9.5:0.5-saturated aq. $\mathrm{NH}_{3}$ ), 40.0; ${ }^{1} \mathrm{H}-\mathrm{NMR}$ $\left(600 \mathrm{MHz} \mathrm{CDCl}_{3} ; \delta\right.$ (ppm), intensity, mult., $\left.J(\mathrm{~Hz})\right): 5.32(1 \mathrm{H}, d t, 5.3,1.9, \mathrm{H}-6), 2.60(1 \mathrm{H}, t t, 4.1,11.5$, H-3), 2.53 (1H, t, 9.2, H-17), 2.17 (1H, $m, \mathrm{H}-16 \beta), 2.15(1 \mathrm{H}, m, \mathrm{H}-4 \beta), 2.12(3 \mathrm{H}, s, \mathrm{H}-21), 2.06(1 \mathrm{H}, m$, $\mathrm{H}-12 \alpha), 2.05(1 \mathrm{H}, m, \mathrm{H}-4 \alpha), 1.98(1 \mathrm{H}, d q, 2.7,5.2, \mathrm{H}-7 \alpha), 1.85(1 \mathrm{H}, d t, 12.7,3.2, \mathrm{H}-1 \beta), 1.83(1 \mathrm{H}, d t, 12.7$, 3.2, H-1 $\alpha), 1.72(1 \mathrm{H}, m, \mathrm{H}-2 \beta), 1.70(1 \mathrm{H}, m, \mathrm{H}-2 \alpha), 1.69(1 \mathrm{H}, m, \mathrm{H}-15 \beta), 1.66(1 \mathrm{H}, m, \mathrm{H}-16 \alpha), 1.62(1 \mathrm{H}, m$, $\mathrm{H}-11 \alpha), 1.57(1 \mathrm{H}, m, \mathrm{H}-7 \beta), 1.47(1 \mathrm{H}, m, \mathrm{H}-8), 1.45(1 \mathrm{H}, m, \mathrm{H}-11 \beta), 1.45(1 \mathrm{H}, m, \mathrm{H}-12 \beta), 1.23(1 \mathrm{H}, m$, $\mathrm{H}-15 \alpha), 1.16(1 \mathrm{H}, m, \mathrm{H}-14), 1.0(1 \mathrm{H}, m, \mathrm{H}-9), 0.99$ (3H, $s, \mathrm{H}-19), 0.63$ (3H, s, H-18). MS $(m / z): 316.2845$ $[\mathrm{M}+\mathrm{H}]^{+}$; calculated for $\mathrm{C}_{21} \mathrm{H}_{34} \mathrm{NO}^{+}$: 316.2640 .

3ß-Holaphyllamine acetamide 2: hRf (silica gel 60 tlc, EtOAc:MeOH, 9.5:0.5-saturated aq. $\mathrm{NH}_{3}$ ), 74.0; ${ }^{1} \mathrm{H}-\mathrm{NMR}\left(600 \mathrm{MHz} \mathrm{CDCl}_{3} ; \delta\right.$ (ppm), intensity, mult., $\left.J(\mathrm{~Hz})\right): 5.36(1 \mathrm{H}, d t, 5.0,2.2, \mathrm{H}-6), 3.70(1 \mathrm{H}, t d d$, 14.8, 8.2, 4.5, H-3), $2.54(1 \mathrm{H}, t, 8.9, \mathrm{H}-17), 2.31(2 \mathrm{H}, d d d, 13.2,4.7,2.2, \mathrm{H}-4), 2.16(1 \mathrm{H}, m, \mathrm{H}-15 \alpha), 2.11$ $(3 \mathrm{H}, s, \mathrm{H}-21), 2.05(1 \mathrm{H}, m, \mathrm{H}-12 \alpha), 1.98(1 \mathrm{H}, m, \mathrm{H}-7 \alpha), 1.95(3 \mathrm{H}, s, \mathrm{H}-23), 1.86(1 \mathrm{H}, m, \mathrm{H}-2 \alpha), 1.85(1 \mathrm{H}, m$, $\mathrm{H}-1 \alpha), 1.68(1 \mathrm{H}, m, \mathrm{H}-16 \alpha), 1.65(1 \mathrm{H}, m, \mathrm{H}-15 \beta), 1.61(1 \mathrm{H}, m, \mathrm{H}-11 \alpha), 1.58(1 \mathrm{H}, m, \mathrm{H}-7 \beta), 1.46(1 \mathrm{H}, m$, $\mathrm{H}-8), 1.45(1 \mathrm{H}, m, \mathrm{H}-12 \beta), 1.45(1 \mathrm{H}, m, \mathrm{H}-11 \beta), 1.35(1 \mathrm{H}, m, \mathrm{H}-2 \beta), 1.20(1 \mathrm{H}, m, \mathrm{H}-16 \beta), 1.17(1 \mathrm{H}, m$, $\mathrm{H}-1 \beta), 1.15(1 \mathrm{H}, m, \mathrm{H}-14), 1.01$ (1H, $m, \mathrm{H}-9), 0.98$ (3H, $s, \mathrm{H}-19), 0.62(3 \mathrm{H}, \mathrm{s}, \mathrm{H}-18)$. MS ( $m / z): 358.3000$ $[\mathrm{M}+\mathrm{H}]^{+}$; calculated for $\mathrm{C}_{23} \mathrm{H}_{36} \mathrm{NO}_{2}{ }^{+}$: 358.2746.

3ß-N-Methylholaphyllamine 3: hRf (silica gel 60 tlc, EtOAc:MeOH, 9.5:0.5-saturated aq. $\mathrm{NH}_{3}$ ), 54.0; ${ }^{1} \mathrm{H}-\mathrm{NMR}\left(600 \mathrm{MHz} \mathrm{CDCl}_{3} ; \delta(\mathrm{ppm})\right.$, intensity, mult., $\left.J(\mathrm{~Hz})\right): 5.40(1 \mathrm{H}, d t, 5.5,2.0, \mathrm{H}-6), 2.76(1 \mathrm{H}, t t, 4.1$, 11.7, H-3), $2.62(3 \mathrm{H}, s, \mathrm{H}-22), 2.54(1 \mathrm{H}, d d, 13.3,2.3, \mathrm{H}-4 \alpha), 2.51(1 \mathrm{H}, d d, 2.4,5.0, \mathrm{H}-17), 2.47(1 \mathrm{H}, d d d$,

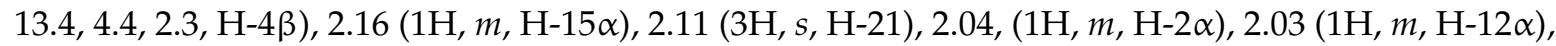
$1.99(1 \mathrm{H}, m, \mathrm{H}-7 \alpha), 1.92(1 \mathrm{H}, m, \mathrm{H}-1 \alpha), 1.82, q d, 12.8,3.6, \mathrm{H}-2 \beta), 1.66(1 \mathrm{H}, m, \mathrm{H}-16 \alpha), 1.64(1 \mathrm{H}, m$, $\mathrm{H}-15 \beta), 1.57(1 \mathrm{H}, m, \mathrm{H}-7 \beta), 1.57(1 \mathrm{H}, m, \mathrm{H}-11 \alpha), 1.46(1 \mathrm{H}, m, \mathrm{H}-8), 1.44(1 \mathrm{H}, m, \mathrm{H}-12 \beta), 1.43(1 \mathrm{H}, m$, $\mathrm{H}-11 \beta), 1.20(1 \mathrm{H}, m, \mathrm{H}-16 \beta), 1.14(1 \mathrm{H}, m, \mathrm{H}-14), 1.08(1 \mathrm{H}, m, \mathrm{H}-1 \beta), 1.01(3 \mathrm{H}, \mathrm{s}, \mathrm{H}-19), 0.98(1 \mathrm{H}, m, \mathrm{H}-9)$, $0.60(3 \mathrm{H}, \mathrm{s}, \mathrm{H}-18)$. MS $(\mathrm{m} / z)$ : $330.2819[\mathrm{M}+\mathrm{H}]^{+}$; calculated for $\mathrm{C}_{22} \mathrm{H}_{36} \mathrm{NO}^{+}: 330.2797$.

$3 \alpha$-Holaphyllamine 4: hRf (silica gel 60 tlc, EtOAc:MeOH, 9.5:0.5-saturated aq. $\mathrm{NH}_{3}$ ), 36.0; ${ }^{1} \mathrm{H}-\mathrm{NMR}$ $\left(600 \mathrm{MHz} \mathrm{CDCl}_{3} ; \delta(\mathrm{ppm})\right.$, intensity, mult., $\left.J(\mathrm{~Hz})\right): 5.33(1 \mathrm{H}, d t, 5.3,2.2, \mathrm{H}-6), 3.16(1 \mathrm{H}, b r . s, \mathrm{H}-3), 2.56$ $(1 \mathrm{H}, m, \mathrm{H}-4 \beta), 2.51(1 \mathrm{H}, t, 9.0, \mathrm{H}-17), 2.15(1 \mathrm{H}, m, \mathrm{H}-16 \beta), 2.10(3 \mathrm{H}, s, \mathrm{H}-21), 2.02(1 \mathrm{H}, m, \mathrm{H}-12 \beta), 1.96$ $(1 \mathrm{H}, m, \mathrm{H}-7 \alpha), 1.88(1 \mathrm{H}, d t, 14.9,2.7, \mathrm{H}-4 \alpha), 1.78(1 \mathrm{H}, d t, 14.1,3.7, \mathrm{H}-2 \beta), 1.65(1 \mathrm{H}, m, \mathrm{H}-15 \beta), 1.62$ $(1 \mathrm{H}, m, \mathrm{H}-16 \alpha), 1.60(1 \mathrm{H}, m, \mathrm{H}-11 \beta), 1.60(1 \mathrm{H}, m, \mathrm{H}-1 \alpha), 1.58(1 \mathrm{H}, m, \mathrm{H}-7 \beta), 1.48(1 \mathrm{H}, m, \mathrm{H}-2 \alpha), 1.44$ $(1 \mathrm{H}, m, \mathrm{H}-8), 1.42(1 \mathrm{H}, m, \mathrm{H}-11 \alpha), 1.42(1 \mathrm{H}, m, \mathrm{H}-12 \alpha), 1.36(1 \mathrm{H}, m, \mathrm{H}-1 \beta), 1.18(1 \mathrm{H}, m, \mathrm{H}-15 \alpha), 1.13$ (1H, $m, \mathrm{H}-14), 1.07(1 \mathrm{H}, m, \mathrm{H}-9), 0.97(3 \mathrm{H}, s, \mathrm{H}-19), 0.60(3 \mathrm{H}, s, \mathrm{H}-18) . \mathrm{MS}(m / z): 316.2827[\mathrm{M}+\mathrm{H}]^{+}$; calculated for $\mathrm{C}_{21} \mathrm{H}_{34} \mathrm{NO}^{+}: 316.2640$.

3ß-Dihydroholaphyllamine 5: hRf (silica gel 60 tlc, EtOAc:MeOH, 9.5:0.5-saturated aq. $\mathrm{NH}_{3}$ ), 42.0; ${ }^{1} \mathrm{H}-\mathrm{NMR}\left(600 \mathrm{MHz} \mathrm{CD}_{3} \mathrm{OD} ; \delta\right.$ (ppm), intensity, mult., $\left.J(\mathrm{~Hz})\right): 3.05(1 \mathrm{H}, t t, 11.9,4.5, \mathrm{H}-3), 2.62(1 \mathrm{H}, t$, 9.1, H-17), $2.12(1 \mathrm{H}, m, \mathrm{H}-16 \alpha), 2.10$ (3H, s, H-21), 2.08, $m, \mathrm{H}-12 \alpha), 2.03(1 \mathrm{H}, d t, 12.1,3.4, \mathrm{H}-12 \beta), 1.86$ $(1 \mathrm{H}, m, \mathrm{H}-2 \beta), 1.84(1 \mathrm{H}, m, \mathrm{H}-2 \alpha), 1.82(1 \mathrm{H}, m, \mathrm{H}-1 \alpha), 1.74(1 \mathrm{H}, m, \mathrm{H}-16 \beta), 1.60(1 \mathrm{H}, m, \mathrm{H}-4 \alpha), 1.42$ $(2 \mathrm{H}, m, \mathrm{H}-5), 1.40(1 \mathrm{H}, m, \mathrm{H}-4 \beta), 1.36(1 \mathrm{H}, m, \mathrm{H}-11 \beta), 1.33(1 \mathrm{H}, m, \mathrm{H}-11 \alpha), 1.32(1 \mathrm{H}, m, \mathrm{H}-6 \alpha), 1.30$ $(1 \mathrm{H}, m, \mathrm{H}-6 \beta), 1.22(1 \mathrm{H}, m, \mathrm{H}-8), 1.21(1 \mathrm{H}, m, \mathrm{H}-14), 1.20(2 \mathrm{H}, m, \mathrm{H}-15), 1.08(1 \mathrm{H}, m, \mathrm{H}-1 \beta), 0.97(2 \mathrm{H}, m$, H-7), 0.86 (3H, s, H-19), 0.78 (1H, $d d d, 12.3,10.7,4.1, \mathrm{H}-9), 0.60$ (3H, s, H-18). MS ( $/ \mathrm{z} / \mathrm{z}): 318.2809$ $[\mathrm{M}+\mathrm{H}]^{+}$; calculated for $\mathrm{C}_{21} \mathrm{H}_{36} \mathrm{NO}^{+}$: 318.2797 .

$3 \alpha$-Dihydroholaphyllamine 6: hRf (silica gel 60 tlc, EtOAc: $\mathrm{MeOH}, 9.5: 0.5$-saturated aq. $\mathrm{NH}_{3}$ ), 23.0; ${ }^{1} \mathrm{H}-\mathrm{NMR}\left(600 \mathrm{MHz} \mathrm{CDCl}_{3} ; \delta\right.$ (ppm), intensity, mult., J (Hz)): $3.21(1 \mathrm{H}$, br s, H-3), $2.52(1 \mathrm{H}, t, 9.0, \mathrm{H}-17)$, $2.14(1 \mathrm{H}, m, \mathrm{H}-16 \beta), 2.11(3 \mathrm{H}, s, \mathrm{H}-21), 2.01(1 \mathrm{H}, d t, 12.2,3.4, \mathrm{H}-12 \beta), 1.74(1 \mathrm{H}, m, \mathrm{H}-2 \alpha), 1.68(1 \mathrm{H}, m$, $\mathrm{H}-1 \alpha), 1.66(1 \mathrm{H}, m, \mathrm{H}-15 \alpha), 1.64(1 \mathrm{H}, m, \mathrm{H}-16 \alpha), 1.62(1 \mathrm{H}, m, \mathrm{H}-11 \alpha), 1.55(1 \mathrm{H}, d d, 3.8,13.5, \mathrm{H}-4 \alpha)$, $1.48(1 \mathrm{H}, m, \mathrm{H}-5), 1.46(1 \mathrm{H}, m, \mathrm{H}-6 \alpha), 1.45(1 \mathrm{H}, m, \mathrm{H}-7 \alpha), 1.44(1 \mathrm{H}, m, \mathrm{H}-6 \beta), 1.39(1 \mathrm{H}, m, \mathrm{H}-12 \alpha), 1.36$ $(1 \mathrm{H}, m, \mathrm{H}-8), 1.28(1 \mathrm{H}, m, \mathrm{H}-7 \beta), 1.26(1 \mathrm{H}, m, \mathrm{H}-11 \beta), 1.21(1 \mathrm{H}, m, \mathrm{H}-4 \beta), 1.20(1 \mathrm{H}, m, \mathrm{H}-2 \beta), 1.17$ 
(1H, m, H-15ß), 1.16 (1H, m, H-14), 0.95 (1H, $m, \mathrm{H}-1 \beta), 0.80$ (1H, td, 3.2, 5.4, H-9), 0.78 (3H, s, H-19), $0.60(3 \mathrm{H}, \mathrm{s}, \mathrm{H}-18)$. MS $(\mathrm{m} / \mathrm{z})$ : $318.2788[\mathrm{M}+\mathrm{H}]^{+}$; calculated for $\mathrm{C}_{21} \mathrm{H}_{36} \mathrm{NO}^{+}$: 318.2797 .

Holadienine 7: hRf (silica gel 60 tlc, EtOAc:MeOH, 9.9:0.1-saturated aq. $\left.\mathrm{NH}_{3}\right), 81.0 ;{ }^{1} \mathrm{H}-\mathrm{NMR}(600 \mathrm{MHz}$ $\mathrm{CDCl}_{3} ; \delta(\mathrm{ppm})$, intensity, mult., $\left.J(\mathrm{~Hz})\right): 7.04(1 \mathrm{H}, d, 10.1, \mathrm{H}-1), 6.22(1 \mathrm{H}, d d, 10.1,1.9, \mathrm{H}-2), 6.07(1 \mathrm{H}, t$,

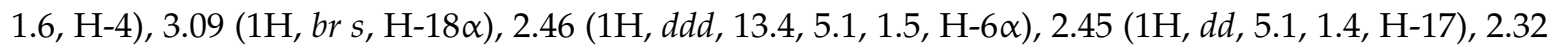
$(1 \mathrm{H}, d d d, 13.3,4.2,2.6, \mathrm{H}-6 \beta), 2.25(3 \mathrm{H}, s, \mathrm{H}-22), 2.04(1 \mathrm{H}, m, \mathrm{H}-7 \alpha), 1.95(1 \mathrm{H}, b r s, \mathrm{H}-18 \beta), 1.85(1 \mathrm{H}, m$, $\mathrm{H}-20), 1.83(1 \mathrm{H}, m, \mathrm{H}-11 \alpha), 1.83(1 \mathrm{H}, m, \mathrm{H}-12 \alpha), 1.76(1 \mathrm{H}, d d, \mathrm{H}-16 \alpha), 1.64(2 \mathrm{H}, q d, \mathrm{H}-15), 1.50(1 \mathrm{H}, q d$, 10.9, 3.8, H-8), $1.43(1 \mathrm{H}, d d, \mathrm{H}-16 \beta), 1.35(1 \mathrm{H}, m, \mathrm{H}-12 \beta), 1.35$ (1H, $m, \mathrm{H}-11 \beta), 1.18(3 \mathrm{H}, s, \mathrm{H}-19), 1.12$ $(1 \mathrm{H}, m, \mathrm{H}-7 \beta), 1.12(1 \mathrm{H}, m, \mathrm{H}-14), 1.08,3 \mathrm{H}, d, \mathrm{H}-21), 1.07(1 \mathrm{H}, \mathrm{m}, \mathrm{H}-9) . \mathrm{MS}(m / z): 326.3834[\mathrm{M}+\mathrm{H}]^{+}$; calculated for $\mathrm{C}_{22} \mathrm{H}_{32} \mathrm{NO}^{+}$: 326.2484 .

Holonamine 8: hRf (silica gel 60 tlc, EtOAc:MeOH, 9.9:0.1-saturated aq. $\left.\mathrm{NH}_{3}\right), 74.0 ;{ }^{1} \mathrm{H}-\mathrm{NMR}(600 \mathrm{MHz}$ $\mathrm{CDCl}_{3} ; \delta(\mathrm{ppm})$, intensity, mult., $\left.J(\mathrm{~Hz})\right): 7.86(1 \mathrm{H}, d, 10.3, \mathrm{H}-4), 7.48(1 \mathrm{H}, d, 3.0, \mathrm{H}-18), 6.15(1 \mathrm{H}, d d, 10.3$, 2.0, H-2), $6.10(1 \mathrm{H}, t, 1.6, \mathrm{H}-1), 4.05-4.10(2 \mathrm{H}, m, \mathrm{H}-11, \mathrm{H}-17),), 2.51(1 \mathrm{H}, t d d, 13.5,5.1,1.5, \mathrm{H}-6 \alpha), 2.39$ $(1 \mathrm{H}, d d d, 13.2,4.4,2.5, \mathrm{H}-6 \beta), 2.19(1 \mathrm{H}, d d, 12.2,4.8, \mathrm{H}-12 \alpha), 2.10(1 \mathrm{H}, m, \mathrm{H}-20), 2.06(1 \mathrm{H}, m, \mathrm{H}-7 \alpha), 1.91$ $(1 \mathrm{H}, q d, 11.4,3.8, \mathrm{H}-8), 1.78(1 \mathrm{H}, d d d, 14.0,8.2,2.8, \mathrm{H}-15 \alpha), 1.68(1 \mathrm{H}, m, \mathrm{H}-16 \alpha), 1.63(1 \mathrm{H}, d d, 12.2,4.8$, $\mathrm{H}-12 \beta), 1.45(1 \mathrm{H}, d d d, 14.2,8.5,3.0, \mathrm{H}-15 \beta), 1.38(1 \mathrm{H}, t d, 11.5,5.3, \mathrm{H}-14), 1.36(3 \mathrm{H}, s, \mathrm{H}-19), 1.35(3 \mathrm{H}, d$, H-21), $1.32(1 \mathrm{H}, m, \mathrm{H}-9), 1.15(1 \mathrm{H}, d d d, 12.8,5.0,3.8, \mathrm{H}-7 \beta), 0,83(1 \mathrm{H}, m, \mathrm{H}-16 \beta)$. MS $(m / z): 326.2000$ $[\mathrm{M}+\mathrm{H}]^{+}$; calculated for $\mathrm{C}_{21} \mathrm{H}_{28} \mathrm{NO}_{2}{ }^{+}$: 326.2120 .

Cona-4,6-dienin-3-one 9: hRf (silica gel 60 tlc, EtOAc:MeOH, 9.9:0.1-saturated aq. $\mathrm{NH}_{3}$ ), 84.0; ${ }^{1} \mathrm{H}-\mathrm{NMR}$ $\left(600 \mathrm{MHz} \mathrm{CDCl}_{3} ; \delta(\mathrm{ppm})\right.$, intensity, mult., $\left.J(\mathrm{~Hz})\right): 6.13(1 \mathrm{H}, m, \mathrm{H}-6), 6.02(1 \mathrm{H}, m, \mathrm{H}-7), 5.64(1 \mathrm{H}, \mathrm{s}, \mathrm{H}-4)$, $2.96(1 \mathrm{H}, d, 10.4, \mathrm{H}-18 \beta), 2.33(1 \mathrm{H}, m, \mathrm{H}-20), 2.32(2 \mathrm{H}, m, \mathrm{H}-2), 2.19(1 \mathrm{H}, m, \mathrm{H}-1 \alpha), 2.16(3 \mathrm{H}, s, \mathrm{H}-22)$, $1.86(1 \mathrm{H}, m, \mathrm{H}-1 \beta), 1.85(1 \mathrm{H}, d, \mathrm{H}-18 \alpha), 1.78(1 \mathrm{H}, d t, 10.7,3.7, \mathrm{H}-17), 1.74(1 \mathrm{H}, d t, 12.2,3.4, \mathrm{H}-12 \alpha), 1.64$ $(2 \mathrm{H}, d d d, 17.1,10.3,4.2, \mathrm{H}-15), 1.58(1 \mathrm{H}, m, \mathrm{H}-16 \alpha), 1.57(1 \mathrm{H}, m, \mathrm{H}-11 \alpha), 1.35(1 \mathrm{H}, d t, 10.8,3.0, \mathrm{H}-8), 1.28$ $(1 \mathrm{H}, t d, 12.8,3.8, \mathrm{H}-12 \beta), 1.14(1 \mathrm{H}, d q, 11.0,2.6, \mathrm{H}-16 \beta), 1.08(1 \mathrm{H}, m, \mathrm{H}-14), 1.04(1 \mathrm{H}, m, \mathrm{H}-11 \beta), 1.05$ (3H, s, H-19), $0.98(3 \mathrm{H}, d, 6.4, \mathrm{H}-21), 0.87(1 \mathrm{H}, d d d, 12.3,10.5,3.6, \mathrm{H}-9) . \mathrm{MS}(m / z): 326.3869[\mathrm{M}+\mathrm{H}]^{+}$; calculated for $\mathrm{C}_{22} \mathrm{H}_{32} \mathrm{NO}^{+}$: 326.2484 .

Cona-3,5-dienin-7-one 10: hRf (silica gel 60 tlc, EtOAc:MeOH, 9.9:0.1-saturated aq. $\mathrm{NH}_{3}$ ), 85.0; ${ }^{1} \mathrm{H}-\mathrm{NMR}$ $\left(600 \mathrm{MHz} \mathrm{CDCl}_{3} ; \delta(\mathrm{ppm})\right.$, intensity, mult., $\left.J(\mathrm{~Hz})\right): 6.14(1 \mathrm{H}, d d d, 9.5,5.4,2.6, \mathrm{H}-3), 6.06(1 \mathrm{H}, d d, 9.7,2.4$, $\mathrm{H}-4), 5.58(1 \mathrm{H}, \mathrm{s}, \mathrm{H}-6), 2.95(1 \mathrm{H}, d, 10.3, \mathrm{H}-18 \alpha), 2.47(1 \mathrm{H}, d d d, 13.0,6.5,4.1, \mathrm{H}-16 \alpha), 2.38(1 \mathrm{H}, d d, 6.5,4.6$, $\mathrm{H}-20), 2.25(2 \mathrm{H}, m, \mathrm{H}-2), 2.22(1 \mathrm{H}, m, \mathrm{H}-8), 2.18(3 \mathrm{H}, s, \mathrm{H}-22), 1.86(1 \mathrm{H}, m, \mathrm{H}-1 \beta), 1.85(1 \mathrm{H}, m, \mathrm{H}-18 \beta)$, $1.78(1 \mathrm{H}, m, \mathrm{H}-12 \beta), 1.74(1 \mathrm{H}, m, \mathrm{H}-17), 1.72(1 \mathrm{H}, m, \mathrm{H}-11 \beta), 1.70(1 \mathrm{H}, m, \mathrm{H}-15 \beta), 1.61(1 \mathrm{H}, m, \mathrm{H}-9)$, $1.42(1 \mathrm{H}, m, \mathrm{H}-14), 1.41(1 \mathrm{H}, m, \mathrm{H}-15 \alpha), 1.39(1 \mathrm{H}, m, \mathrm{H}-16 \beta), 1.31(1 \mathrm{H}, m, \mathrm{H}-1 \alpha), 1.30(1 \mathrm{H}, m, \mathrm{H}-12 \alpha)$, $1.23(1 \mathrm{H}, m, \mathrm{H}-11 \alpha), 1.03(3 \mathrm{H}, \mathrm{s}, \mathrm{H}-19), 1.02(3 \mathrm{H}, d, 6.3, \mathrm{H}-21) . \mathrm{MS}(\mathrm{m} / z): 326.3871[\mathrm{M}+\mathrm{H}]^{+}$; calculated for $\mathrm{C}_{22} \mathrm{H}_{32} \mathrm{NO}^{+}$: 326.2484 .

Conessimine 11: hRf (silica gel 60 tlc, EtOAc:MeOH, 9.9:0.1-saturated aq. $\mathrm{NH}_{3}$ ), 47.0; ${ }^{1} \mathrm{H}-\mathrm{NMR}$ (600 MHz CDCl ${ }_{3} ; \delta(\mathrm{ppm})$, intensity, mult., $\left.J(\mathrm{~Hz})\right): 5.35(1 \mathrm{H}, d t, 5.1,1.8, \mathrm{H}-6), 3.19(1 \mathrm{H}, q d, 6.5,4.7$, H-20), $2.79(1 \mathrm{H}, d, 12.1, \mathrm{H}-18 \beta), 2.52$ (1H, $d, 12.1, \mathrm{H}-18 \alpha), 2.27$ (6H, $s, \mathrm{H}-22, \mathrm{H}-23), 2.19(2 \mathrm{H}, m, \mathrm{H}-4)$, $2.10(1 \mathrm{H}, m, \mathrm{H}-3), 2.08(1 \mathrm{H}, m, \mathrm{H}-7 \alpha), 2.05(1 \mathrm{H}, m, \mathrm{H}-7 \beta), 1.94(1 \mathrm{H}, m, \mathrm{H}-1 \alpha), 1.89(1 \mathrm{H}, m, \mathrm{H}-17), 1.88$ $(1 \mathrm{H}, m, \mathrm{H}-12 \alpha), 1.78(1 \mathrm{H}, m, \mathrm{H}-2 \alpha), 1.69(1 \mathrm{H}, m, \mathrm{H}-16 \alpha), 1.69(1 \mathrm{H}, m, \mathrm{H}-11 \alpha), 1.64(1 \mathrm{H}, m, \mathrm{H}-15 \alpha), 1.51$ $(1 \mathrm{H}, m, \mathrm{H}-15 \beta), 1.46(1 \mathrm{H}, m, \mathrm{H}-2 \beta), 1.41(1 \mathrm{H}, m, \mathrm{H}-12 \beta), 1.32(1 \mathrm{H}, m, \mathrm{H}-8), 1.31(1 \mathrm{H}, m, \mathrm{H}-14), 1.23$ (1H, $m, \mathrm{H}-11 \beta), 1.16(1 \mathrm{H}, m, \mathrm{H}-16 \beta), 1.12(3 \mathrm{H}, d, 6.6, \mathrm{H}-21), 1.08(1 \mathrm{H}, m, \mathrm{H}-1 \beta), 0.99(1 \mathrm{H}, m, \mathrm{H}-9), 0.93$ $(3 \mathrm{H}, \mathrm{s}, \mathrm{H}-19)$. MS ( $\mathrm{m} / \mathrm{z})$ : $343.4082[\mathrm{M}+\mathrm{H}]^{+}$; calculated for $\mathrm{C}_{23} \mathrm{H}_{39} \mathrm{~N}_{2}{ }^{+}: 343.3113$.

Isoconessimine 12: hRf (silica gel 60 tlc, EtOAc: $\mathrm{MeOH}, 9.9: 0.1$-saturated aq. $\mathrm{NH}_{3}$ ), 55.0; ${ }^{1} \mathrm{H}-\mathrm{NMR}$ $\left(600 \mathrm{MHz} \mathrm{CDCl}_{3} ; \delta\right.$ (ppm), intensity, mult., $\left.J(\mathrm{~Hz})\right): 5.37(1 \mathrm{H}, t d, 5.0,2.2, \mathrm{H}-6), 3.30(1 \mathrm{H}, d, 11.3, \mathrm{H}-18 \alpha)$, $2.73(1 \mathrm{H}, m, \mathrm{H}-20), 2.59(1 \mathrm{H}, m, \mathrm{H}-3), 2.54(3 \mathrm{H}, s, \mathrm{H}-23), 2.42(3 \mathrm{H}, s, \mathrm{H}-22), 2.35(2 \mathrm{H}, m, \mathrm{H}-4), 2.12(1 \mathrm{H}, m$, $\mathrm{H}-18 \beta), 2.08(1 \mathrm{H}, t d, 5.4,2.0, \mathrm{H}-7 \alpha), 1.97(1 \mathrm{H}, m, \mathrm{H}-17), 1.92(1 \mathrm{H}, m, \mathrm{H}-2 \alpha), 1.89(1 \mathrm{H}, m, \mathrm{H}-1 \alpha), 1.82$ $(1 \mathrm{H}, m, \mathrm{H}-12 \beta), 1.82(1 \mathrm{H}, m, \mathrm{H}-15 \alpha), 1.68(1 \mathrm{H}, m, \mathrm{H}-16 \alpha), 1.67(1 \mathrm{H}, m, \mathrm{H}-11 \alpha), 1.61(1 \mathrm{H}, m, \mathrm{H}-2 \beta), 1.60$ $(1 \mathrm{H}, m, \mathrm{H}-7 \beta), 1.51(1 \mathrm{H}, d t, 10.7,2.8, \mathrm{H}-15 \beta), 1.40(1 \mathrm{H}, d d, 11.3,4.1, \mathrm{H}-12 \alpha), 1.34(1 \mathrm{H}, m, \mathrm{H}-8), 1.31$ 
(1H, $m, \mathrm{H}-16 \beta), 1.19$ (3H, $d, 6.5, \mathrm{H}-21), 1.17$ (1H, $m, \mathrm{H}-11 \beta), 1.16(1 \mathrm{H}, m, \mathrm{H}-14), 1.08$ (1H, $m, \mathrm{H}-1 \beta), 0.97$ $(1 \mathrm{H}, m, \mathrm{H}-9), 0.94(3 \mathrm{H}, \mathrm{s}, \mathrm{H}-19)$. MS $(m / z): 343.4055$ [M + H]; calculated for $\mathrm{C}_{23} \mathrm{H}_{39} \mathrm{~N}_{2}{ }^{+}: 343.3113$

Conessine 13: hRf (silica gel 60 tlc, EtOAc:MeOH, 9.9:0.1-saturated aq. $\left.\mathrm{NH}_{3}\right), 70.0 ;{ }^{1} \mathrm{H}-\mathrm{NMR}(600 \mathrm{MHz}$ $\mathrm{CDCl}_{3} ; \delta(\mathrm{ppm})$, intensity, mult., $\left.J(\mathrm{~Hz})\right): 5.32(1 \mathrm{H}, m, \mathrm{H}-6), 2.97(1 \mathrm{H}, d, 10.3, \mathrm{H}-18 \alpha), 2.34(1 \mathrm{H}, m, \mathrm{H}-20)$, $2.27(6 \mathrm{H}, s, \mathrm{H}-23,24), 2.18(3 \mathrm{H}, s, \mathrm{H}-22), 2.18(2 \mathrm{H}, m, \mathrm{H}-4), 2.09(1 \mathrm{H}, m, \mathrm{H}-3), 2.06(1 \mathrm{H}, m, \mathrm{H}-7 \alpha), 1.87$ $(1 \mathrm{H}, m, \mathrm{H}-1 \alpha), 1.85(1 \mathrm{H}, m, \mathrm{H}-18 \beta), 1.82(1 \mathrm{H}, m, \mathrm{H}-17), 1.76(1 \mathrm{H}, m, \mathrm{H}-12 \alpha), 1.73(1 \mathrm{H}, m, \mathrm{H}-2 \alpha), 1.68$ $(1 \mathrm{H}, m, \mathrm{H}-15 \alpha), 1.63(1 \mathrm{H}, m, \mathrm{H}-11 \alpha), 1.61(1 \mathrm{H}, m, \mathrm{H}-11 \beta), 1.59(2 \mathrm{H}, m, \mathrm{H}-16), 1.58(1 \mathrm{H}, m, \mathrm{H}-7 \beta), 1.41$ (1H, $m, \mathrm{H}-2 \beta), 1.39$ (1H, $m, \mathrm{H}-15 \beta), 1.36(1 \mathrm{H}, m, \mathrm{H}-8), 1.33(1 \mathrm{H}, m, \mathrm{H}-12 \beta), 1.10(1 \mathrm{H}, m, \mathrm{H}-14), 1.04$ $(1 \mathrm{H}, m, \mathrm{H}-1 \beta), 1.01(3 \mathrm{H}, d, 6.3, \mathrm{H}-21), 0.93(1 \mathrm{H}, m, \mathrm{H}-9), 0.90(3 \mathrm{H}, s, \mathrm{H}-19)$. MS $(m / z): 357.4072[\mathrm{M}+\mathrm{H}]^{+}$; calculated for $\mathrm{C}_{24} \mathrm{H}_{41} \mathrm{~N}_{2}{ }^{+}: 357.3270$

Holarrhesine 14: hRf (silica gel 60 tlc, EtOAc:MeOH, 9.9:0.1-saturated aq. $\mathrm{NH}_{3}$ ), 69.0; ${ }^{1} \mathrm{H}-\mathrm{NMR}$ (600 MHz CDCl 3 ; $\delta(\mathrm{ppm})$, intensity, mult., $J(\mathrm{~Hz})): 5.34(1 \mathrm{H}, \mathrm{m}, \mathrm{H}-6), 5.31\left(1 \mathrm{H}, d d t, 7.3,2.9,1.4, \mathrm{H}-3^{\prime}\right)$, $4.89(1 \mathrm{H}, d d, 11.3,4.2, \mathrm{H}-12), 3.02\left(2 \mathrm{H}, d p, 7.3,1.0, \mathrm{H}-2^{\prime}\right), 2.84(1 \mathrm{H}, d, 10.1, \mathrm{H}-18 \beta), 2.41(3 \mathrm{H}, \mathrm{s}, \mathrm{H}-23)$, $2.34(1 \mathrm{H}, d, 10.2, \mathrm{H}-18 \alpha), 2.32(1 \mathrm{H}, m, \mathrm{H}-20), 2.27(1 \mathrm{H}, m, \mathrm{H}-3), 2.24(1 \mathrm{H}, d d, 4.3,2.1, \mathrm{H}-4 \alpha), 2.22(3 \mathrm{H}, s$, $\mathrm{H}-22), 2.10(1 \mathrm{H}, m, \mathrm{H}-17), 2.08(1 \mathrm{H}, m, \mathrm{H}-7 \alpha), 2.00(1 \mathrm{H}, m, \mathrm{H}-4 \beta), 1.78(1 \mathrm{H}, m, \mathrm{H}-11 \alpha), 1.78(1 \mathrm{H}, m$, $\mathrm{H}-1 \alpha), 1.74\left(3 \mathrm{H}, s, \mathrm{H}-5^{\prime}\right), 1.71(1 \mathrm{H}, m, \mathrm{H}-15 \beta), 1.65(2 \mathrm{H}, m, \mathrm{H}-16), 1.65\left(3 \mathrm{H}, s, \mathrm{H}-6^{\prime}\right), 1.58(1 \mathrm{H}, m, \mathrm{H}-7 \beta)$, $1.39(1 \mathrm{H}, m, \mathrm{H}-15 \alpha), 1.38(1 \mathrm{H}, m, \mathrm{H}-8), 1.27(1 \mathrm{H}, m, \mathrm{H}-2 \beta), 1.25(1 \mathrm{H}, m, \mathrm{H}-2 \alpha), 1.20(1 \mathrm{H}, m, \mathrm{H}-11 \beta), 1.20$ $(1 \mathrm{H}, m, \mathrm{H}-14), 1.12(1 \mathrm{H}, m, \mathrm{H}-9), 1.08(1 \mathrm{H}, m, \mathrm{H}-1 \beta), 0.98$ (3H, $d, 6.4, \mathrm{H}-21), 0.93(3 \mathrm{H}, s, \mathrm{H}-19) . \mathrm{MS}(m / z)$ : $455.5514[\mathrm{M}+\mathrm{H}]$; calculated for $\mathrm{C}_{29} \mathrm{H}_{47} \mathrm{~N}_{2} \mathrm{O}_{2}{ }^{+}$: 455.3638 .

Holarrhetine 15: hRf (silica gel 60 tlc, EtOAc:MeOH, 9.9:0.1-saturated aq. $\mathrm{NH}_{3}$ ), 73.0; ${ }^{1} \mathrm{H}-\mathrm{NMR}$ $\left(600 \mathrm{MHz} \mathrm{CDCl}_{3} ; \delta\right.$ (ppm), intensity, mult., $\left.J(\mathrm{~Hz})\right): 5.32(1 \mathrm{H}, d t, 4.1,1.6, \mathrm{H}-6), 5.30(1 \mathrm{H}, d d t, 7.1,2.7,1.4$, $\left.\mathrm{H}-3^{\prime}\right), 4.89(1 \mathrm{H}, d d, 11.1,4.2, \mathrm{H}-12), 3.01\left(2 \mathrm{H}, d p, 7.5,1.0, \mathrm{H}-2^{\prime}\right), 2.84(1 \mathrm{H}, d, 10.2, \mathrm{H}-18 \alpha), 2.34(1 \mathrm{H}, d$, 10.4, H-18ß), 2.32 (1H, $m, \mathrm{H}-20), 2.28$ (6H, $s, \mathrm{H}-23, \mathrm{H}-24), 2.22$ (3H, s, H-22), $2.16(2 \mathrm{H}, m, \mathrm{H}-4), 2.10$ $(1 \mathrm{H}, m, \mathrm{H}-17), 2.08(1 \mathrm{H}, m, \mathrm{H}-3), 2.06(1 \mathrm{H}, m, \mathrm{H}-7 \alpha), 1.82(1 \mathrm{H}, m, \mathrm{H}-1 \alpha), 1.78(1 \mathrm{H}, d d, 10.0,4.9, \mathrm{H}-11 \alpha)$, $1.72(1 \mathrm{H}, m, \mathrm{H}-15 \beta), 1.72(1 \mathrm{H}, m, \mathrm{H}-2 \alpha), 1.70\left(3 \mathrm{H}, s, \mathrm{H}-5^{\prime}\right), 1.64\left(3 \mathrm{H}, s, \mathrm{H}-6^{\prime}\right), 1.64(1 \mathrm{H}, m, \mathrm{H}-16 \alpha), 1.58$ $(1 \mathrm{H}, m, \mathrm{H}-7 \beta), 1.38(1 \mathrm{H}, m, \mathrm{H}-2 \beta), 1.38(1 \mathrm{H}, m, \mathrm{H}-15 \alpha), 1.34(1 \mathrm{H}, d d, \mathrm{H}-8), 1.25(1 \mathrm{H}, m, \mathrm{H}-16 \beta), 1.20$ $(1 \mathrm{H}, d d, \mathrm{H}-14), 1.16(1 \mathrm{H}, d d, 6.6,3.1, \mathrm{H}-11 \beta), 1.12(1 \mathrm{H}, d d, 3.6,2.2, \mathrm{H}-9), 1.05(1 \mathrm{H}, m, \mathrm{H}-1 \beta), 0.98(3 \mathrm{H}, d$, 6.4, $\mathrm{H}-21), 0.92(3 \mathrm{H}, \mathrm{s}, \mathrm{H}-19)$. MS $(\mathrm{m} / \mathrm{z})$ : $469.5725[\mathrm{M}+\mathrm{H}]^{+}$; calculated for $\mathrm{C}_{30} \mathrm{H}_{49} \mathrm{~N}_{2} \mathrm{O}_{2}{ }^{+}$: 469.3794 .

Holarrheline 16: hRf (silica gel 60 tlc, EtOAc:MeOH, 9.9:0.1-saturated aq. $\mathrm{NH}_{3}$ ), 31.0; ${ }^{1} \mathrm{H}-\mathrm{NMR}$ $\left(600 \mathrm{MHz} \mathrm{CD}_{3} \mathrm{OD} ; \delta\right.$ (ppm), intensity, mult., $\left.J(\mathrm{~Hz})\right): 5.35(1 \mathrm{H}, d t, 5.4,1.8, \mathrm{H}-6), 3.58(1 \mathrm{H}, d d, 11.0,4.2$, $\mathrm{H}-12), 2.77(1 \mathrm{H}, d, 10.5, \mathrm{H}-18 \alpha), 2.67(1 \mathrm{H}, q d, 6.4,4.9, \mathrm{H}-20), 2.41(1 \mathrm{H}, d, 10.5, \mathrm{H}-18 \beta), 2.36(3 \mathrm{H}, s, \mathrm{H}-23)$, $2.28(1 \mathrm{H}, m, \mathrm{H}-4 \alpha), 2.27(1 \mathrm{H}, m, \mathrm{H}-3), 2.25(3 \mathrm{H}, s, \mathrm{H}-22), 2.19(1 \mathrm{H}, d d d, 10.8,4.9,3.0, \mathrm{H}-17), 2.09(1 \mathrm{H}, t d$, 5.3, 2.6, H-7 $\alpha), 2.05(1 \mathrm{H}, m, \mathrm{H}-4 \beta), 1.88(1 \mathrm{H}, m, \mathrm{H}-1 \alpha), 1.82(1 \mathrm{H}, m, \mathrm{H}-2 \beta), 1.73(1 \mathrm{H}, m, \mathrm{H}-15 \beta), 1.73$ $(1 \mathrm{H}, m, \mathrm{H}-11 \alpha), 1.64(1 \mathrm{H}, m, \mathrm{H}-16 \beta), 1.60(1 \mathrm{H}, m, \mathrm{H}-7 \beta), 1.44(1 \mathrm{H}, m, \mathrm{H}-15 \alpha), 1.34(1 \mathrm{H}, m, \mathrm{H}-2 \alpha), 1.33$ $(1 \mathrm{H}, m, \mathrm{H}-8), 1.32(1 \mathrm{H}, m, \mathrm{H}-16 \alpha), 1.15(1 \mathrm{H}, t d, 6.3,1.5, \mathrm{H}-14), 1.13(1 \mathrm{H}, m, \mathrm{H}-11 \beta), 1.10(1 \mathrm{H}, m, \mathrm{H}-1 \beta)$, $1.08(1 \mathrm{H}, m, \mathrm{H}-9), 1.04(3 \mathrm{H}, d, 6.5, \mathrm{H}-21), 0.95(3 \mathrm{H}, \mathrm{s}, \mathrm{H}-19)$. MS $(\mathrm{m} / \mathrm{z}): 359.4531[\mathrm{M}+\mathrm{H}]^{+}$; calculated for $\mathrm{C}_{23} \mathrm{H}_{39} \mathrm{~N}_{2} \mathrm{O}^{+}: 359.3062$.

Holarrhenine 17: hRf (silica gel 60 tlc, EtOAc:MeOH, 9.9:0.1-saturated aq. $\mathrm{NH}_{3}$ ), 55.0; ${ }^{1} \mathrm{H}-\mathrm{NMR}$ (600 MHz CD $\mathrm{MD}_{3} \delta$ (ppm), intensity, mult., $\left.J(\mathrm{~Hz})\right): 5.35(1 \mathrm{H}, \mathrm{dt}, 5.3,1.9, \mathrm{H}-6), 3.58(1 \mathrm{H}, \mathrm{dd}, 11.1,4.2$, $\mathrm{H}-12), 2.78(1 \mathrm{H}, \mathrm{d}, 10.5, \mathrm{H}-18 \beta), 2.68(1 \mathrm{H}, m, \mathrm{H}-20), 2.41(1 \mathrm{H}, d, 10.6, \mathrm{H}-18 \alpha), 2.27(6 \mathrm{H}, s, \mathrm{H}-23, \mathrm{H}-24)$, $2.25(3 \mathrm{H}, s, \mathrm{H}-22), 2.23(1 \mathrm{H}, m, \mathrm{H}-4 \alpha), 2.18(1 \mathrm{H}, m, \mathrm{H}-4 \beta), 2.18(1 \mathrm{H}, m, \mathrm{H}-14), 2.10(1 \mathrm{H}, m, \mathrm{H}-3), 2.07$ $(1 \mathrm{H}, m, \mathrm{H}-7 \alpha), 1.90(1 \mathrm{H}, m, \mathrm{H}-1 \beta), 1.78(2 \mathrm{H}, m, \mathrm{H}-2), 1.73(1 \mathrm{H}, m, \mathrm{H}-11 \alpha), 1.72(1 \mathrm{H}, m, \mathrm{H}-15 \alpha), 1.64$ (1H, $m, \mathrm{H}-16 \alpha), 1.58(1 \mathrm{H}, m, \mathrm{H}-7 \beta), 1.46(1 \mathrm{H}, m, \mathrm{H}-15 \beta), 1.32(1 \mathrm{H}, m, \mathrm{H}-8), 1.30(1 \mathrm{H}, m, \mathrm{H}-16 \beta), 1.15$ $(1 \mathrm{H}, m, \mathrm{H}-17), 1.11(1 \mathrm{H}, m, \mathrm{H}-11 \beta), 1.07(1 \mathrm{H}, m, \mathrm{H}-1 \alpha), 1.06(1 \mathrm{H}, m, \mathrm{H}-9), 1.04(3 \mathrm{H}, d, 6.5, \mathrm{H}-21), 0.95$ (3H, s, H-19). MS (m/z): $373.4399[\mathrm{M}+\mathrm{H}]^{+}$; calculated for $\mathrm{C}_{24} \mathrm{H}_{41} \mathrm{~N}_{2} \mathrm{O}^{+}: 373.3219$.

Kurchinin 18: ${ }^{1} \mathrm{H}-\mathrm{NMR}\left(600 \mathrm{MHz} \mathrm{CDCl}_{3} ; \delta\right.$ (ppm), intensity, mult., $\left.J(\mathrm{~Hz})\right): 7.74(1 \mathrm{H}, d, 10.3, \mathrm{H}-1), 6.15$ $(1 \mathrm{H}, d d, 2.0,10.3, \mathrm{H}-2), 6.10(1 \mathrm{H}, t, 1.6, \mathrm{H}-4), 4.10(1 \mathrm{H}, t t, 6.1,10.1, \mathrm{H}-11), 2.52(1 \mathrm{H}, d d, 5.0,1.3, \mathrm{H}-16 \alpha)$, $2.49(1 \mathrm{H}, d t, 3.6,1.3, \mathrm{H}-6 \beta), 2.47(1 \mathrm{H}, d t, 7.7,1.2, \mathrm{H}-16 \beta), 2.43(1 \mathrm{H}, d q, 4.3,2.5, \mathrm{H}-6 \alpha), 2.22(1 \mathrm{H}, d t, 5.0$, 
12.5, H-12 $\alpha), 2.08(1 \mathrm{H}, d d d, 6.4,4.0,1.5, \mathrm{H}-7 \alpha), 1.96(1 \mathrm{H}, d d d d, 12.5,9.0,5.9,1.2, \mathrm{H}-15 \alpha), 1.83(1 \mathrm{H}, d t d$, 11.0, 3.8, 12.1, H-8), 1.57 (1H, m, H-15ß), 1.35 (1H, ddd, 11.7, 5.9, 1.3, H-14), 1.32 (3H, s, H-19), 1.25 $(1 \mathrm{H}, m, \mathrm{H}-12 \beta), 1.17(1 \mathrm{H}, m, \mathrm{H}-7 \beta), 1.16(1 \mathrm{H}, m, \mathrm{H}-9), 0.95(3 \mathrm{H}, s, \mathrm{H}-18) . \mathrm{MS}(m / z): 301.3773[\mathrm{M}+\mathrm{H}]^{+}$; calculated for $\mathrm{C}_{19} \mathrm{H}_{25} \mathrm{O}_{3}: 301.1804$.

$N^{3}$-Isopentenyl adenine 19: ${ }^{1} \mathrm{H}-\mathrm{NMR}\left(600 \mathrm{MHz} \mathrm{CDCl}_{3} ; \delta(\mathrm{ppm})\right.$, intensity, mult., J (Hz)): $8.06(1 \mathrm{H}, s$, H-8), 8.01 (1H, s, H-2), 5.51 (1H, m, H-12), 5.00 (2H, d, 7.5, H-11), 1.85 (3H, s, H-14), 1.82 (3H, s, H-15). MS $(m / z): 204.1475[\mathrm{M}+\mathrm{H}]^{+}$; calculated for $\mathrm{C}_{10} \mathrm{H}_{14} \mathrm{~N}_{5}{ }^{+}: 204.1249$.

All the spectra data were in full agreement with reported literature data [21-31].

\subsection{In Vitro Biological Assays}

In vitro tests for biological activity of the crude extracts, fractions, sub-fractions and isolated compounds against Trypanosoma brucei rhodesiense (bloodstream trypomastigotes, STIB 900 strain), Trypanosoma cruzi (amastigotes, Tulahuen C4 strain), Leishmania donovani (amastigotes, MHOM-ET-67/ L82 strain), Plasmodium falciparum (intraerythrocytic form, NF54 strain) and cytotoxicity test against mammalian L6 cell line from rat skeletal myoblasts were performed according to the established standard protocol [33]. However, only the activity data against Trypanosoma brucei rhodesiense is reported due to the inactivity of the tested substances against other parasites at the concentration tested.

\section{Conclusions}

Steroid alkaloids from Holarrhena africana have proved to be an interesting new class of highly active and selective lead compounds against Trypanosoma brucei rhodesiense. Of the 17 steroid alkaloids isolated, eight were identified to possess significant antitrypanosomal activity with $I C_{50}$ values well below $1 \mu \mathrm{M}$ and represent potential candidates for further study. Some SARs were observed which indicates that a $\Delta^{5,6}$ steroid nucleus with a monomethyl amino group at C-3 and a pyrrolidine ring with the amino nitrogen placed between C-20 and C-18 represents an optimum, among the compounds isolated so far, for high antitrypanosomal activity and selectivity. This essential pharmacophoric requirement for active and selective anti-trypanosomal activity is currently under refinement in terms of 3D QSAR modelling; this modeling will provide more detailed explanations to the present findings and possibly allow activity predictions for yet untested compounds of this type, aiming at structural optimization.

Supplementary Materials: Supplementary materials are available online. The ${ }^{1} \mathrm{H}$ and ${ }^{13} \mathrm{C}$ NMR of all the isolated compounds are provided as supplementary Figures S1-S38.

Acknowledgments: We thank the Federal Government of Nigeria for a doctoral fellowship to Charles Nnadi at WWU, Münster through the Tertiary Education Trust Fund (TETFund) and the University of Nigeria Nsukka. This work is an activity within the Research Network Natural Products against Neglected Diseases (ResNet NPND, www.resnetnpnd.org).

Author Contributions: C.O.N. collected the plant materials, isolated and characterized the compounds, and wrote the initial draft of the manuscript. R.B. and M.K. performed the in vitro biological activity tests. T.J.S. and N.J.N. conceived and initiated the project. T.J.S. supervised the entire study and wrote the final draft of the manuscript.

Conflicts of Interest: The authors declare no conflict of interest.

\section{References}

1. Hotez, P.J.; Alvarado, M.; Basáñez, M.; Bolliger, I.; Bourne, R.; Boussinesq, M.; Brooker, S.J.; Brown, A.S.; Buckle, G.; Budke, C.M.; et al. The Global Burden of Disease Study 2010: Interpretation and Implications for the Neglected Tropical Diseases. PLoS Negl. Trop. Dis. 2014, 8, e2865. [CrossRef] [PubMed]

2. Fèvre, E.M.; Odiit, M.; Coleman, P.G.; Welburn, S.C.; Woolhouse, M.E.J. Estimating the burden of rhodesiense sleeping sickness during an outbreak in Serere, eastern Uganda. BMC Public Health 2008, 8, 96. [CrossRef] [PubMed] 
3. Fèvre, E.M.; Wissmann, B.V.; Welburn, S.C.; Lutumba, P. The Burden of Human African Trypanosomiasis. PLoS Negl. Trop. Dis. 2008, 2, e333. [CrossRef] [PubMed]

4. Weiss, M.G. Stigma and the social burden of neglected tropical diseases. PLoS Negl. Trop. Dis. 2008, 2, e237. [CrossRef] [PubMed]

5. Hopp, K.H.; Cunningham, L.V.; Bromel, M.C.; Schermeister, L.J.; Khalil, S.K. In vitro antitrypanosomal activity of certain alkaloids against Trypanosma lewisi. Lloydia 1976, 39, 375-377. [PubMed]

6. Hoet, S.; Stévigny, C.; Block, S.; Opperdoes, F.; Colson, P.; Baldeyrou, B.; Lansiaux, A.; Bailly, C.; Quetin-Leclercq, J. Alkaloids from Cassytha filiformis and related aporphines: Antitrypanosomal activity, cytotoxicity, and interaction with DNA and topoisomerases. Planta Med. 2004, 70, 407-413. [PubMed]

7. Nibret, E.; Sporer, F.; Asres, K.; Wink, M. Antitrypanosomal and cytotoxic activities of pyrrolizidine alkaloid-producing plants of Ethiopia. J. Pharm. Pharmacol. 2009, 61, 801-808. [CrossRef] [PubMed]

8. Scotti, M.T.; Speck-Planche, A.; Tavares, J.F.; da Silva Sobral, M.; Natália, M.; Cordeiro, D.S.; Scotti, L. Virtual Screening of Alkaloids from Apocynaceae with Potential Antitrypanosomal Activity. J. Curr. Bioinform. 2015, 10, 509-519. [CrossRef]

9. Merschjohann, K.; Sporer, F.; Steverding, D.; Wink, M. In Vitro Effect of Alkaloids on Bloodstream Forms of Trypanosoma brucei and T. congolense. Planta Med. 2001, 67, 623-627. [CrossRef] [PubMed]

10. Toriizukaa, Y.; Kinoshitaa, E.; Kogurea, N.; Kitajimaa, M.; Ishiyamab, A.; Otogurob, K.; Yamadab, H.; Ōmurab, S.; Takayama, H. New lycorine-type alkaloid from Lycoris traubii and evaluation of antitrypanosomal and antimalarial activities of lycorine derivatives. Bioorg. Med. Chem. 2008, 16, 10182-10189. [CrossRef] [PubMed]

11. Camacho, M.; Phillipson, J.D.; Croft, S.L.; Rock, P.; Marshall1, S.J.; Schiff, P.L., Jr. In-vitro activity of Triclisia patens and some bisbenzylisoquinoline alkaloids against Leishmania donovani and Trypanosoma brucei brucei. Phytother. Res. 2002, 16, 432-436. [CrossRef] [PubMed]

12. Bringmann, G.; Hoerr, V.; Holzgrabe, U.; Stich, A. Antitrypanosomal naphthylisoquinoline alkaloids and related compounds. Die Pharm. 2003, 58, 343-346.

13. Murebwayirea, S.; Frédérichb, M.; Hannaertc, V.; Jonvilleb, M.C.; Duez, P. Antiplasmodial and antitrypanosomal activity of Triclisia sacleuxii (Pierre) Diels. Phytomedicine 2008, 15, 728-733. [CrossRef] [PubMed]

14. Feng, Y.; Davis, R.A.; Sykes, M.L.; Avery, V.M.; Carroll, A.R.; Camp, D.; Quinn, R.J. Anti-trypanosomal pyridoacridine alkaloids from the Australian ascidian Polysyncraton echinatum. Tetrahedron Lett. 2010, 51, 2477-2479. [CrossRef]

15. Schmidt, T.J.; Khalid, S.A.; Romanha, A.J.; Alves, T.M.; Biayatti, M.W.; Brun, R.; Da Costa, F.B.; de Castro, S.L.; Ferreira, V.F.; de Lacerda, M.V.; et al. The potential of secondary metabolites from plants as drugs or leads against protozoan neglected diseases-Part II. Curr. Med. Chem. 2012, 19, 2176-2228. [PubMed]

16. Raffauf, R.F.; Flagler, M.B. Alkaloids of the Apocynaceae. Econ. Bot. 1960, 14, 37-55. [CrossRef]

17. Bever, B.O. Medicinal plants in tropical West Africa. J. Ethnopharmacol. 1982, 5, 1-71. [CrossRef]

18. Bogne, K.P.; Penlap, B.V.; Lontsi-David, E.F. Antibacterial activities of the extracts and conessine from Holarrhena floribunda G. DON. (Apocynaceae). Afr. J. Tradit. Complement. Altern. Med. 2007, 4, 352-356. [PubMed]

19. Fotie, J.; Scott, B.D.; MaraLeimanis, L.; Elias, G.; Geoffrey, R.; Nkenfack, E. Lupeol long-chain fatty acid esters with antimalarial activity from Holarrhena floribunda. J. Nat. Prod. 2006, 69, 62-67. [CrossRef] [PubMed]

20. Nwodo, N.J.; Brun, R.; Osadebe, P.O. In-vitro and in-vivo evaluation of the antitrypanosomal activity of fractions of Holarrhena africana. J. Ethnopharmacol. 2007, 113, 556-559. [CrossRef] [PubMed]

21. Kam, T.; Sim, K.; Koyano, K.; Toyoshima, M.; Hayashi, M.; Komiyama, K. Cytotoxic and Leishmanicidal Aminoglycosteroids and Aminosteroids from Holarrhena curtisii. J. Nat. Prod. 1998, 61, 1332-1336. [CrossRef] [PubMed]

22. Kasal, A.; Budesinsky, M.; Griffiths, W.J. Spectroscopic Methods of Steroid Analysis. In Steroid Analysis, 2nd ed.; Makin, H.L.J., Gower, D.B., Eds.; Springer Science + Business Media B.V.: Dordrecht, The Netherlands, 2010; Volume 90.

23. Zirihi, G.N.; Grellier, P.; Guede-Guina, F.; Bodo, B.; Mambu, L. Isolation, characterization and anti-plasmodial activity of steroidal alkaloids from Funtumia elastica (Preuss) Stapf. Bioorg. Med. Chem. Lett. 2005, 15, 2637-2640. [CrossRef] [PubMed] 
24. Xie, H.; Su, J.; Ge, X.; Dong, T.; Li, X.; Wen, H.; Sun, B. Compounds with inhibitory activity on peristalsis from the seeds of Holarrhena antidysenterica. Nat. Prod. Res. 2017. [CrossRef] [PubMed]

25. Yang, Z.D.; Duan, D.Z.; Xue, W.W.; Yao, X.J.; Li, S. Steroidal alkaloids from Holarrhena antidysenterica as acetylcholinesterase inhibitors and the investigation for structure-activity relationships. Life Sci. 2012, 90, 929-933. [CrossRef] [PubMed]

26. Siddiqui, B.S.; Usmani, S.B.; Begum, S.; Siddiqui, C. Steroidal alkaloids and an androstane derivative from the bark of Holarrhena pubescens. Phytochemistry 1993, 33, 925-928. [CrossRef]

27. Cerny, V.; Sorm, F. Steroid Alkaloids: Alkaloids of apocynaceae and buxaceae. In The Alkaloids: Chemistry and Physiology; Academic Press: New York, NY, USA, 1967; Volume 9, pp. 305-426.

28. Hitchin, J.R.; Hamilton, N.M.; Jordan, A.M.; Lyons, A.J.; Ogilvie, D.J. A novel scalable and stereospecific synthesis of $3 \alpha$ - and $3 \beta$-amino- $5 \alpha$-androstan-17-ones and $3 \alpha$ - and $3 \beta$-amino- $5 \alpha$-pregnan-20-ones. Tetrahedron Lett. 2012, 53, 2868-2872. [CrossRef]

29. Einhorn, J.; Monneret, C.; Khuong-Huu, Q. Alcaloïdes des feuilles de l'Holarrhena crassifolia. Phytochemistry 1972, 11, 769-777. [CrossRef]

30. Wagner, H.; Seegert, K.; Sonnenbichler, H.; Ilyas, M.; Odenthal, K.P. Steroidal alkaloids of Funtumia africana. Planta Med. 1987, 53, 444-449. [CrossRef] [PubMed]

31. Vicha, J.; Malon, M.; Vesela, P.; Humpa, O.; Strnad, M.; Marek, R. ${ }^{1} \mathrm{H}-,{ }^{13} \mathrm{C}-$, and ${ }^{15} \mathrm{~N}$ - NMR chemical shifts for selected glucosides and ribosides of aromatic cytokinins. Magn. Reson. Chem. 2010, 48, 318-322. [CrossRef] [PubMed]

32. Theodorou, V.; Skobridis, K.; Tzakos, A.G.; Ragoussis, V. A simple method for the alkaline hydrolysis of esters. Tetrahedron Lett. 2007, 48, 8230-8233. [CrossRef]

33. Nour, A.M.M.; Khalid, S.A.; Kaiser, M.; Brun, R.; Abdallah, W.E.; Schmidt, T.J. The Antiprotozoal Activity of Sixteen Asteraceae Species Native to Sudan and Bioactivity-Guided Isolation of Xanthanolides from Xanthium brasilicum. Planta Med. 2009, 75, 1363-1368. [CrossRef] [PubMed]

Sample Availability: Samples of the compounds 3, 8, 11, 14, 15, 16, 17, 19 are available from the authors.

(C) 2017 by the authors. Licensee MDPI, Basel, Switzerland. This article is an open access article distributed under the terms and conditions of the Creative Commons Attribution (CC BY) license (http://creativecommons.org/licenses/by/4.0/). 